\title{
EXPANSÃO INTRAURBANA COMO ALTERNATIVA Estudo dos territórios de projeto urbano no Arco Tietê, São Paulo
}

\author{
Marlon Rubio Longo \\ Universidade de São Paulo - Faculdade de Arquitetura e Urbanismo \\ Orientação: Prof. Dra. Regina Maria Prosperi Meyer \\ Mail: marlonrl@usp.br
}

\section{RESUMO}

Os problemas derivados da dispersão urbana tem levado uma série de planos e projetos públicos recentes a adotarem medidas que incentivam a intensificação dos usos e o aumento das densidades no espaço intraurbano, com recorrente menção ao conceito de cidade compacta. $O$ artigo debate esse tema na Região Metropolitana de São Paulo, identificando territórios prioritários para intervenção junto aos trechos com boa oferta de infraestrutura de transporte e alto grau de ociosidade. Para tanto, foi realizado um levantamento de áreas passíveis de transformação e feitas simulações de densidade, demonstrando o potencial de crescimento ainda existente dentro da área urbanizada. $\mathrm{O}$ artigo recorta um tema específico de pesquisa mais ampla, que busca identificar o papel das redes de mobilidade na delimitação de territórios de interesse metropolitano, nos quais o fomento a projetos urbanos passa a ser uma ação estratégica para qualificação do meio urbano.

Palavras-chave: Projeto urbano, Urbanização dispersa, Cidade Compacta, São Paulo.

\begin{abstract}
The urban sprawl issues have been contributed to several public plans and projects committed to measures that encourage the density increases and the maximization of uses in intra-urban land, with a recurrent mention of compact city concept. This paper discusses this subject in the São Paulo Metropolitan Area, in order to identify priority areas for urban development, being focused on regions with an strong supply of transportation infrastructure and a high level of obsolescence. Thus, not only have we selected some potential transformation sites, but also some density simulations were developed, demonstrating the current urban growth potential within the urbanized area. The study outlines a specific topic of a broader research that debates the role of mobility networks in the delimitation of territories of metropolitan interest, where the promotion of urban projects becomes a strategic action to qualify the urban environment.
\end{abstract}

Keywords: Urban project, Urban sprawl, Compact City, São Paulo. 


\section{PREÂMBULO}

O presente artigo faz parte da pesquisa de doutorado intitulada "Redes de mobilidade e os territórios de projeto urbano em São Paulo", que iniciou-se em 2018. A pesquisa estuda, no contexto da metrópole de São Paulo, a relação entre as redes de mobilidade de alta capacidade existente e planejada e os recortes territoriais definidos como áreas de interesse metropolitano, trechos fundamentais para o funcionamento da metrópole, por concentrarem funções públicas de interesse comum aos diversos municípios, e estratégicos para recepcionar futuros projetos urbanos.

No resumo inicial enviado para este Seminário, afirmávamos que as redes de mobilidade exercem a importante função de reorientar as atividades urbanas por meio da alteração dos padrões de acessibilidade, ativando áreas que se convertem em territórios prioritários de projeto e levando, assim, a um novo padrão de crescimento compacto da área urbanizada. $\mathrm{O}$ avaliador do artigo, então, observou que seria necessário esclarecer tal argumento, uma vez que a lógica é que as redes de mobilidade contribuam para maior expansão da mancha urbana.

O estudo apresentado neste artigo aborda um tema específico da pesquisa em desenvolvimento: seria possível identificarmos territórios ou áreas de projeto urbano junto a atual rede de mobilidade de alta capacidade, de forma a apontar alternativas ao processo de expansão horizontal da mancha urbana? Optamos neste artigo, portanto, por redirecionar o amplo debate colocado no resumo inicial, com o intuito de explorar um tema específico da pesquisa.

\section{INTRODUÇÃO}

O fenômeno da expansão urbana ilimitada, observado a partir do espraiamento descontínuo da área urbanizada, tem se desdobrado em pautas desafiadoras nas últimas décadas, dentre as quais destacamos: a pressão para expansão e manutenção das diversas redes de infraestrutura públicas, o crescimento do tecido urbano sobre as áreas ambientalmente sensíveis, a dependência do automóvel, o alto custo econômico e social dos movimentos pendulares e a crônica desigualdade na distribuição de empregos, serviços e equipamentos nas áreas metropolitanas.

A consciência sobre esse novo padrão da urbanização passou a fazer parte dos debates e da literatura norte-americana a partir da década de 1960, coincidindo com a intensificação do fenômeno, embora a tendência aos movimentos centrífugos de crescimento urbano já fizesse parte daquele contexto pelo menos desde meados do século dezenove, como pontua Monclús (1996). No Brasil, como identificado por Reis (2006), tais processos tornaram-se evidentes a partir das décadas de 1980 e 1990, sendo fortemente estudados, sobretudo nos campos da geografia e do urbanismo, e ganhado presença na literatura acadêmica ao longo dos anos 2000 , revelando-se ainda hoje como um tema de pesquisa necessário frente a intensidade dos problemas que se estendem em cidades grandes e médias.

Em todo caso, embora esse processo de urbanização apresente causas e consequências com certos traços de similaridade em diferentes contextos - sendo o exemplo norte-americano o mais explorado - devemos notar também suas singulares. No caso de São Paulo, foco deste artigo, o processo não deve ser observado unicamente pelo ângulo do subúrbio de baixa densidade, com tipologias unifamiliares ocupando grandes lotes e um público de média e alta renda. Na realidade, tal situação descreve apenas uma das múltiplas características que definem a construção desse território heterogêneo.

O presente artigo debate precisamente o fenômeno da urbanização extensiva, bem como os argumentos que visam oferecer alternativas ao processo, sobretudo a oportunidade de incentivar o crescimento urbano em trechos bem servidos de infraestrutura, cuja capacidade de suporte justifique o aumento da densidade populacional. Para tanto, mobiliza autores e teorias que se cruzam em dois campos do conhecimento - 0 urbanismo e a economia urbana - reiterando que a complementaridade entre ambos é extremamente produtiva, pois trata-se da observação plural de um fenômeno complexo e, portanto, dependente de uma abordagem multidisciplinar. 
O trabalho visa demonstrar o potencial de crescimento intraurbano ${ }^{1} \mathrm{em}$ um território específico da metrópole de São Paulo: o Arco Tietê da Macroárea de Estruturação Metropolitana, recorte presente do Plano Diretor Estratégico (PDE) de São Paulo (Lei 16.050 de 2014). Tal escolha baseou-se tanto nas características quanto nos objetivos e vocações pretendidos pela MEM dentro do PDE.

O artigo estrutura-se em três partes: na primeira, busca discutir as bases teóricas responsáveis por fundamentar a questão da expansão intraurbana, focando na contraposição entre os temas da urbanização extensiva e da cidade compacta. Na sequência, apresenta a metodologia para selecionar os recortes territoriais na área de estudo de forma que, na terceira parte seja possível realizar estimativas de produção habitacional e adensamento populacional dentro do Arco Tietê.

\subsection{A MACROÁREA DE ESTRUTURAÇÃO METROPOLITANA (MEM)}

O PDE define macroáreas como porções homogêneas do território, cujo objetivo é orientar o desenvolvimento urbano e aplicar instrumentos urbanísticos e ambientais específicos. Seus recortes variam tanto em função do grau de consolidação urbana da área quanto a partir de suas fragilidades ou potencialidades ambientais.

A MEM (Imagem 01) está dividida em duas grandes áreas nas quais são atribuídos objetivos específicos: o Setor Orla Ferroviária e Fluvial é caracterizado por glebas derivadas do parcelamento industrial e remanescentes da implantação da infraestrutura ferroviária, pela oferta de empregos e pela ausência de número expressivo de habitações, ou seja, redesenhar os vazios, promover o adensamento populacional e modernizar as infraestruturas instaladas são demandas dessa área; já os Eixos de Desenvolvimento Econômico localizam-se em áreas com adensamento populacional, porém com tecido urbano fragmentado e baixa oferta de empregos, sendo necessário o incentivo a novas dinâmicas econômicas, além da qualificação dos tecidos de bairro, muitos deles cindidos pela infraestrutura rodoviária implantada (FRANCO et al, 2015).

Ademais, uma das características fundamentais da MEM é promover importantes transformações não somente em âmbito municipal, mas principalmente metropolitano, sendo capaz de articular os polos e demais municípios da Região Metropolitana de São Paulo (RMSP), justamente pela marcante presença dos eixos de transporte de pessoas e produtos - a ferrovia, as rodovias e as avenidas estruturais. $O$ fato de operar simultaneamente em escala local e metropolitana, pretendendo conciliar os objetivos do planejamento do espaço intraurbano e do espaço regional, é a característica que permite a MEM um objetivo ambicioso: reequilibrar dinâmicas e deslocamentos metropolitanos por meio de ações de projeto urbano. Tal reequilíbrio fundamenta-se nas lógicas do PDE a partir da redistribuição da oferta de trabalho e moradia, promovida tanto pelo incentivo a novas centralidades quanto pelas conexões entre os polos de empregos dos diversos municípios da RMSP.

Na escala regional, a presença da MEM alinha-se ao Plano de Desenvolvimento Urbano Integrado da RMSP, atualmente em desenvolvimento e fruto do também recém aprovado Estatuto da Metrópole (Lei Federal no13.089 de 2015). Um marco importante do Estatuto é justamente a definição de Funções Públicas de Interesse Comum, ou seja, ações ou políticas cuja realização isolada por parte de um município seja inviável ou cause impacto nos municípios vizinhos.

\subsection{O SETOR ARCO TIETÊ}

O Arco Tietê é um recorte localizado ao longo da orla ferroviária e cujos limites aproximam-se do desenho da cota da várzea do rio Tietê. Com uma área de mais de 5 mil hectares, trata-se de um recorte que interseciona 8 prefeituras regionais, cuja extensão territorial aproxima-se a de Manhattan (Figura 02).

\footnotetext{
${ }^{1}$ Utilizamos o termo intraurbano no mesmo sentido que Villaça (2001: Cap.2) para diferenciar os processos que ocorrem no arranjo interno dos espaços urbanos, diferenciando daqueles que ocorrem no espaço regional.
} 


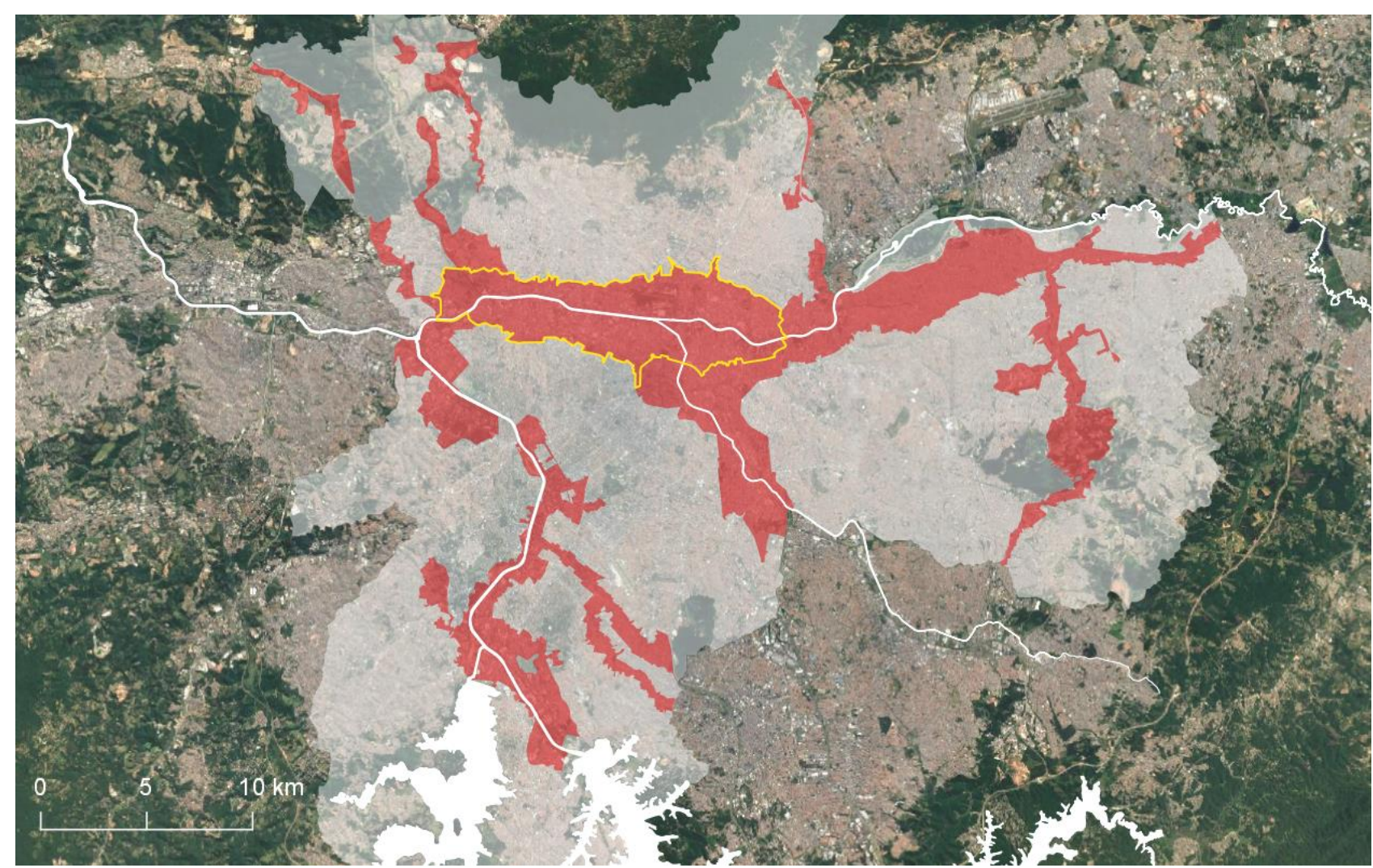

Figura 01: MEM (vermelho) e o Arco Tietê (amarelo) dentro do município de São Paulo (branco).

Fonte: Imagem do autor, dados PMSP e Google Earth, 2017

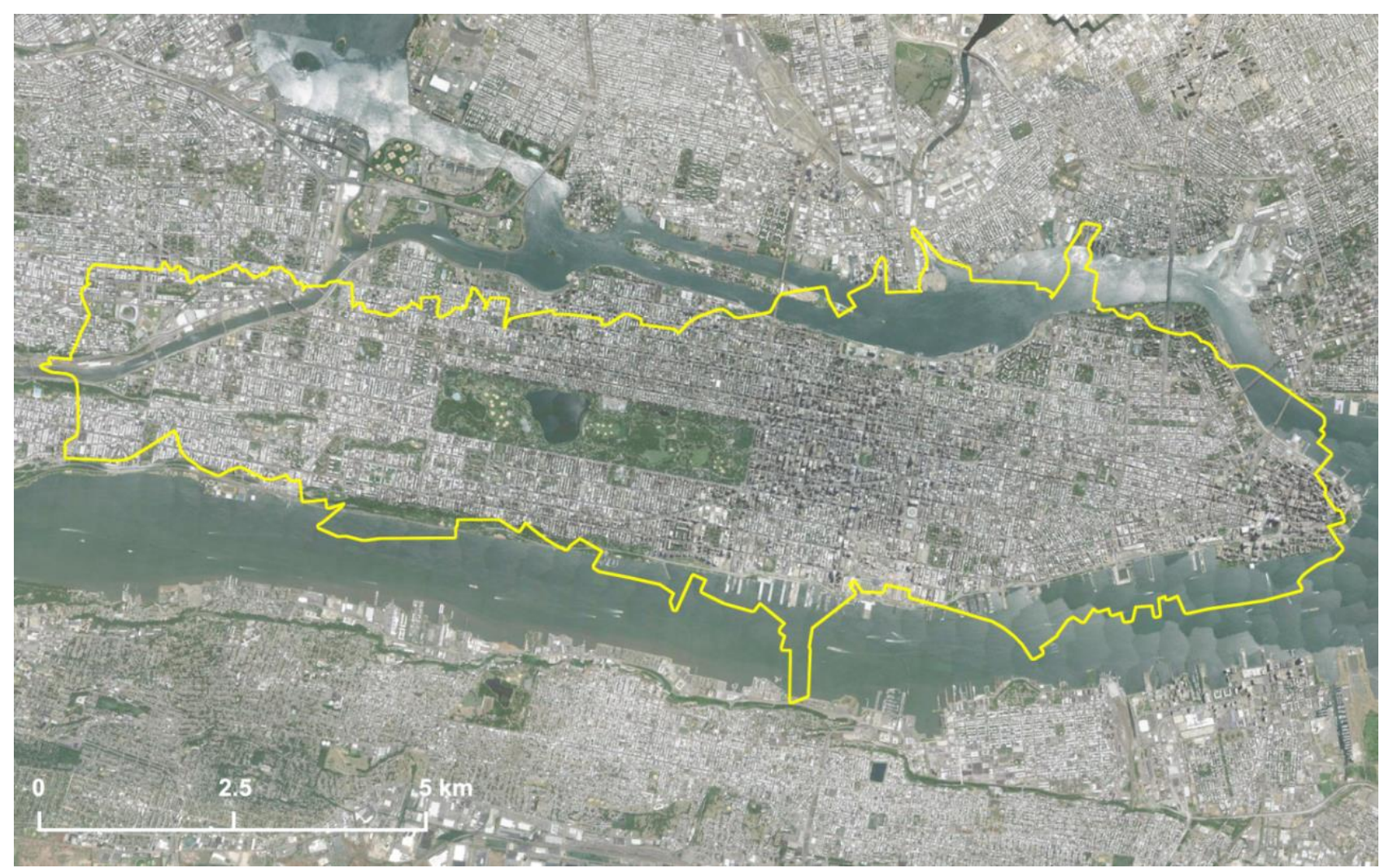

Figura 02: Perímetro do Arco Tietê sobre Manhattan, NY.

Fonte: Imagem do autor, dados PMSP e Google Earth, 2017 
Dadas as proporções, o Arco Tietê apresenta uma heterogeneidade muito grande, contando com bairros consolidados com altas densidades e predomínio de uso misto, outros nos quais prevalece o uso residencial e baixas densidades - sobretudo aqueles situados ao norte do Arco Tietê -, além de grandes áreas com boa oferta de empregos e infraestrutura, porém contando com as mais baixas densidades habitacionais.

O PDE define o Arco Tietê como uma área estratégica tanto pela presença da rica infraestrutura de transporte - contanto com vias estruturais, metrô e ferrovia - quanto pelo grande número de glebas e lotes disponíveis para desenvolvimento urbano futuro, fruto do padrão de ocupação do solo vinculado aos usos industriais que se implantaram em boa parte da MEM e impulsionaram a economia e a urbanização paulistana ao longo do século vinte.

Com uma densidade populacional bruta média de pouco mais 63 habitantes por hectare (CENSO 2010), o potencial urbanístico do Arco Tetê reside, por um lado, no estímulo a implantação de novos postos de emprego e na manutenção da atividade industrial em alguns trechos, inclusive com proposta de conversão para industria leve ligada a tecnologia e, por outro, na transformação do uso e ocupação do solo, prevendo o incremento habitacional e o surgimento de bairros mistos de alta densidade, em consonância com a presença da rede de transporte público de massa.

Portanto, a escolha do Arco Tietê para este artigo se deu pelo seu potencial inerente de desenvolvimento e transformação, dada a presença de áreas passíveis de projeto ao longo da rede de transporte de alta capacidade, estando aptas a receber um conjunto de atividades e moradias que intensifiquem o uso do solo intraurbano. Tal estratégia coloca-se, evidentemente, como alternativa à lógica de expansão urbana periférica, em uma tentativa de evidenciar o potencial dos vazios internos à mancha urbana, invertendo-se, dessa forma, a pressão da recorrente fragmentação do tecido urbano nas bordas da metrópole.

\section{EXPANSÃO INTRAURBANA COMO ALTERNATIVA AO ESPRAIAMENTO}

Em estudo realizado em $2016^{2}$, Angel e colaboradores analisam os padrões de urbanização - a partir da análise da forma da mancha urbana e do crescimento populacional - em cerca de 4.200 cidades com mais de 100.000 habitantes, observando dados a partir da década de 1990. Por meio de análise empírica utilizando geoprocessamento, o estudo parte da observação da área urbanizada em três períodos (1990, $2000,2014)$, demarcando os perímetros ocupados pela mancha urbana nos diferentes momentos.

Parte significativa do estudo consiste na definição das principais formas de expansão da mancha urbana, sendo possível caracterizar quatro tipos básicos: o primeiro, denominado crescimento por preenchimento - ou, mais precisamente o que foi nomeado neste artigo como expansão intraurbana - corresponde a ocupação dos vazios intraurbanos, ou seja, áreas que permaneceram desocupadas apesar da expansão do tecido urbano ao redor; segundo, é proposto o crescimento por extensão, caracterizando o surgimento de novas áreas urbanas de forma contígua e contínua em relação à área urbanizada já existente; terceiro, trata-se do crescimento descontínuo, que corresponde ao aparecimento de novos trechos de tecido urbano desconectados da mancha urbana existente, ou seja, diz respeito justamente ao que se denominou neste artigo como espraiamento urbano; por fim, é proposto o crescimento por inclusão: trechos urbanizados que por ventura já estavam desconectados da mancha urbana e que foram alcançados pela expansão contínua da mesma (ANGEL et al, 2016: p.26) ${ }^{3}$.

Considerando um conjunto de metrópoles latino-americanas analisadas pelo estudo (São Paulo, Cidade do México, Buenos Aires e Bogotá), notam-se duas características importantes (ver Tabela 01). Primeiramente, o predomínio das formas de expansão intraurbana e por extensão em todo o período analisado (1990 a 2014), demonstrando que o crescimento contínuo da área urbanizada ainda é uma realidade nas grandes cidades da região. Por outro lado, chama a atenção os baixos índices de crescimento descontínuo ou por espraiamento, que encontrará razões específicas em cada contexto.

\footnotetext{
${ }^{2} \mathrm{O}$ estudo denominado foi publicado inicialmente em 2012 pelo Lincoln Institute of Land Policy, contanto com um universo de pesquisa com cerca de 3600 cidades com mais de 100.000 habitantes. Ademais, o trabalho faz referência a estudos anteriores do mesmo autor, com destaque para "The Dynamics of Global Urban Expansion" (ANGEL et al, 2005).

${ }^{3}$ Os temos são traduções nossas a partir dos originais: Infill, Extension, Leapfrog e Inclusion.
} 


\begin{tabular}{l|c|c|c|c|c|c|c|c}
\hline \multirow{2}{*}{$\begin{array}{l}\text { Forma de } \\
\text { expansão da área }\end{array}$} & \multicolumn{2}{|c|}{ São Paulo } & \multicolumn{2}{c|}{ Cidade do México } & \multicolumn{2}{c|}{ Buenos Aires } & \multicolumn{2}{c}{ Bogotá } \\
\cline { 2 - 11 } & 1990 & 2000 & 1990 & 2000 & 1990 & 2000 & 1990 & 2000 \\
- & - & - & - & - & - & - \\
2 & 2000 & 2000 & 2014 & 2000 & 2014 \\
\hline Intraurbana & $53 \%$ & $59 \%$ & $44 \%$ & $37 \%$ & $48 \%$ & $59 \%$ & $42 \%$ & $59 \%$ \\
\hline Por extensão & $20 \%$ & $22 \%$ & $42 \%$ & $49 \%$ & $30 \%$ & $34 \%$ & $41 \%$ & $34 \%$ \\
\hline Descontínua & $3 \%$ & $2 \%$ & $1 \%$ & $0 \%$ & $2 \%$ & $0 \%$ & $0 \%$ & $0 \%$ \\
\hline Por inclusão & $16 \%$ & $16 \%$ & $14 \%$ & $13 \%$ & $20 \%$ & $18 \%$ & $17 \%$ & $7 \%$ \\
\hline
\end{tabular}

Tabela 1: Percentuais das diferentes formas de expansão da área urbanizada.

Fonte: (ANGEL et al, 2016)

No caso de São Paulo, por exemplo, devemos pontuar que grande parte do que é considerado expansão intraurbana pelo estudo (que chega a atingir 59\% entre 2000 e 2014), poderia ser classificado também como crescimento descontínuo ao mudarmos nossa escala de observação. Ou seja, núcleos urbanos ou ocupações que surgiram nos últimos anos ao longo dos principais eixos rodoviários, demarcados no estudo como parcelas de expansão intraurbana, coincidem com um processo mais amplo de urbanização. Isto é possível pois o conjunto de regiões metropolitanas que forma a chamada Macrometrópole Paulista ${ }^{4}$ é articulado principalmente a partir da potente rede rodoviária existente, cujas áreas de influência convertemse em territórios estratégicos para instalação de produção e escoamento industrial, atividades de logística, núcleos empresariais e enclaves residenciais, como os loteamentos fechados.

Ao observarmos mais atentamente tais áreas, é possível constatar a quase total ausência de contiguidade do tecido urbano existente e a forte dependência em relação aos eixos principais de mobilidade, que passam a ser os elementos de vínculo desses pedaços de cidade - características muito similares aos padrões de expansão urbana descontínua. Nesse sentido, os eixos rodoviários e ferroviários, além de poderosos conectores entre as diferentes regiões metropolitanas, transformam-se em protagonistas do processo de dispersão urbana, alimentando o surgimento de trechos cada vez mais autônomos e que se justapõem de forma descontínua, com presença marcante de vazios urbanos (MONCLÚS, 1996, p.07).

É necessário notar, ademais, que a presença expressiva de áreas vazias não ocorre somente nas chamadas áreas periurbanas, ou seja, nos trechos onde se percebe com menos clareza a distinção entre áreas urbanas e rurais. O surgimento de vazios intraurbanos acontece muitas vezes nas áreas de influência das infraestruturas de mobilidade e correlacionam-se diretamente com o processo de dispersão. Como proposto por Reis (2006), esse conjunto de mudanças que caracteriza a urbanização dispersa tem produzido padrões muito diversos de conformação do tecido urbano, não restringindo-se somente às bordas da mancha urbana. Exemplos significativos do processo podem ser observados nas áreas ao longo dos eixos do metrô e também junto às marginais, cujos centros de comércio e serviços que ali se instalaram "(...) atendem as demandas das áreas de dispersão e das outras áreas metropolitanas do sistema" (REIS, 2006: p.82) - considerações que podem ser diretamente observadas ao longo do Arco Tietê.

A presença significativa de vazios frente à dimensão da área urbanizada da metrópole e todos os problemas derivados dela, tais como as baixas densidades e o tempo despendido nos deslocamentos pendulares, obriga urbanistas e órgãos públicos de planejamento a multiplicar os argumentos a favor da intensificação do uso do solo intraurbano, em uma clara tentativa de induzir o crescimento urbano junto às áreas mais bem servidas de infraestrutura, sobretudo de transporte de massa. Diante desse cenário, tornase pertinente um debate preliminar a respeito de ambos os processos: a urbanização dispersa ou extensiva e os argumentos favoráveis a cidade compacta e suas premissas. Ambos os temas são essenciais para compreendermos o que está em jogo no setor Arco Tietê.

\footnotetext{
${ }^{4}$ A Macrometrópole Paulista é um território oficial e que congrega hoje um total de 173 municípios, com cerca de 30 milhões de habitantes segundo dados do IBGE (2010). É composta por um total de 5 regiões metropolitanas: São Paulo, Campinas, Baixada Santista, Sorocaba e Vale do Paraíba e Litoral Norte.
} 


\subsection{A URBANIZAÇÃO EXTENSIVA E A PERMANÊNCIA DOS VAZIOS INTRAURBANOS}

Do ponto de vista da análise físico-territorial, Nestor Gourlart Reis, que organizou e produziu recentemente ampla bibliografia sobre o tema da dispersão urbana em São Paulo, sintetiza o fenômeno a partir das seguintes características: primeiro, verifica-se o esgarçamento do tecido urbano dos principais núcleos, em suas áreas periféricas; segundo, a formação de nebulosas de núcleos e bairros isolados em meio ao campo e integradas a um conjunto de sistema de áreas metropolitanas; terceiro, a transformação no transporte cotidiano de passageiros na metrópole, de forma a converter a infraestrutura rodoviária em vias expressas inter e intrametropolitanas; e, for fim, a difusão de um modo de vida e de consumo metropolitanos que se dispersam entre esses núcleos (REIS, 2006: p.13).

Para Meyer e Grostein (2006) é preciso inicialmente diferenciar o processo de conurbação que caracterizou a forma de urbanização da metrópole industrial, dos processos recentes de urbanização extensiva ou de dispersão urbana, sobretudo se observados na escala da Macrometrópole Paulista. Para as autoras, a distinção entre ambos os processos é proveniente de suas relações com os diferentes sistemas produtivos: enquanto a conurbação dos municípios se associava ao período de instalação da indústria pesada, reforçando a monocentralidade do município sede, a urbanização dispersa associa-se a uma reorganização das funções produtivas sob a ótica da policentralidade (MEYER; GROSTEIN, 2006: p.48).

No entanto, apesar da forma de expansão urbana da metrópole industrial ter seguido um padrão diferente do atual, não se trata da existência de um corte abrupto ou da substituição completa de uma pela outra. A complexidade existente na metrópole de São Paulo resulta em uma verdadeira sobreposição de processos, construindo ocupações urbanas heterogêneas (SPOSITO, 2009). Como colocado por Grostein (2015, p.46), podemos observar esse processo como a persistência do padrão periférico ${ }^{5}$ de expansão urbana - ou como denominado pela autora, um padrão periférico urbano-regional - resultando na conjugação entre fragilidade ambiental, a presença de assentamentos precários, e a multiplicação de empreendimentos imobiliários residenciais exclusivos - na forma de condomínios ou mesmo loteamentos fechados. Podemos falar então, na coexistência de uma periferia metropolitana ainda com seus traços de precarização e irregularidade e de novas áreas periféricas de escala urbano-regional, as quais apresentam certo grau de qualificação, visto que são trechos fragmentados porém conectados e com presença de infraestrutura instalada.

Primeiramente, é preciso notar que tais leituras revelam características específicas atribuídas a urbanização extensiva de São Paulo, diferenciando-se em parte do padrão norte-americano. Sobre esse aspecto, um exemplo claro diz respeito à questão da densidade populacional: enquanto o subúrbio norte-americano tem a predominância de tipologias unifamiliares resultando em extensas áreas de baixa densidade, em São Paulo nota-se a presença simultânea desse padrão e de trechos periféricos de média e alta densidade, ocupados em geral por habitações irregulares e de baixa renda.

A relação entre densidade e espraiamento é fundamental, pois ao justapormos ambos os conceitos com o fato já conhecido da existência de glebas vazias e bem localizadas no Arco Tietê, constatamos a incoerência desse processo. Pelo menos em teoria, na medida em vislumbramos um aumento da demanda por imóveis, tais áreas poderiam ser gradativamente ocupadas, o que, como se sabe, não ocorre.

Portanto, é necessário compreender preliminarmente quais forças são capazes de promover a expansão do tecido urbano e de que forma isso acontece. No campo da economia urbana, um dos modelos amplamente utilizados para investigar os processos de urbanização corresponde ao da cidade monocêntrica, desenvolvido nos trabalhos de Willian Alonso (1964), Richard Muth (1969) e Edwin Mills (1967). Como colocado por Brueckner (2011: p.25), o modelo está baseado em simplificações estratégicas, justamente para facilitar as análises e capturar os elementos essenciais do processo de urbanização. Em sua versão básica, o modelo propõe uma cidade com um único centro de empregos, ao redor do qual distribuem-se as áreas residenciais, além de considerar que os custos de transporte aumentam uniformemente na medida em que nos distanciamos do centro. Como o modelo define a mesma utilidade para todo o espaço urbano, intui-se que o valor das unidades residenciais diminui para compensar os custos de transporte mais altos nas bordas da cidade.

\footnotetext{
${ }^{5}$ A expressão padrão periférico de urbanização é largamente utilizada por uma série de autores, com destaque para Bonduki (1987), que analisaram o processo de formação das grandes áreas periféricas de São Paulo, vinculadas à instalação da indústria e seu papel polarizador em escala nacional.
} 
Utilizando esse modelo e propondo a inclusão de novas variáveis, Brueckner (2011) traz contribuições importantes para compreendermos os fundamentos do processo de expansão da mancha urbana. Para o autor, é possível observar uma disputa nas bordas da urbanização, promovida pela competição entre a renda da terra urbana e da terra rural, avançando sobre o vizinho aquela parcela cujo uso tenha maior relevância econômica. O processo como um todo é explicado pelo autor da seguinte forma: considere que uma cidade tenha, em um dado momento, um excesso de demanda por habitação; esse excesso gera, em teoria, um aumento generalizado no preço dos imóveis, sendo que uma das consequências é a própria redução da área das tipologias e a verticalização em todas as áreas da cidade; tal processo levaria também a um aumento generalizado da densidade populacional, bem como a elevação da renda da terra urbana para os proprietários em toda a cidade; como resultado final, a mancha urbana tenderia a se expandir, de forma a garantir um novo equilíbrio entre oferta e demanda (BRUECKNER, 2011: p.44).

Contudo, ainda que esse itinerário de transformações do modelo inicial seja coerente, ele não explica dois fatores básicos da dispersão urbana, como colocado anteriormente: a presença de baixas densidades e a recorrência de vazios. Nesse sentido, autores atribuem essas incongruências a algumas falhas de mercado (BURCHFIELD et al, 2006: p.609; BRUECKNER, 2011: p.73), dentre as quais são citadas: o valor das áreas livres, seja do ponto de vista ambiental, mas também social, como qualificadoras do entorno urbanizado; a intensificação dos congestionamentos e suas externalidades negativas em áreas com aumento elevado de densidade; ou mesmo considerar os edifícios existentes como bens duráveis e com custo de transformação elevado, dificultando assim sua substituição.

No caso específico de São Paulo, algumas dessas falhas estão claramente expressas nas condicionantes da dispersão urbana, como é o caso dos congestionamentos e a busca por amenidades ambientais que levaram, sobretudo a partir da década de 1980, ao surgimento dos loteamentos fechados de baixa densidade fora da mancha urbana. Ademais, devemos pontuar que grande parte da demanda habitacional ao longo do período de instalação da indústria pesada correspondeu à população de baixa renda, incapaz de acessar o mercado formal, instalando-se em áreas periféricas.

No setor Arco Tietê, assim como em boa parte da MEM, podemos apontar ainda outras duas hipóteses que poderiam servir para explicar a presença marcante dos vazios. A primeira, é que os vazios urbanos hoje encontrados, em sua maioria, estavam previamente ocupadas por indústrias ao longo das linhas férreas e territórios de várzea, fruto da formação da metrópole industrial ao longo do século vinte. Na medida em que observamos um crescente movimento de saída dessa atividade ${ }^{6}$, grandes glebas resultantes da ocupação horizontal dos galpões industriais passaram a surgir, transformando-se novamente em ativos imobiliários. Segundo, podemos falar também na retenção especulativa dessas áreas, tendo em vista a grande expectativa gerada por projetos promovidos pelo poder público.

Embora existam externalidades negativas produzidas pela existência dos vazios em áreas estratégicas, como é o caso do Arco Tietê, Brueckner (2011: p.79) propõe que a vacância também possa ser vista de forma positiva, pois abre a chance de desenvolvimento futuro de bairros mais densos. Portanto, as áreas vazias da MEM representam uma oportunidade para avançarmos na construção de alternativas para melhoria da vida urbana na metrópole, sobretudo se pensarmos na possibilidade de implementação de tecidos urbanos compactos, com alta acessibilidade e grande oferta de habitação para diferentes faixas de renda.

\subsection{ACESSIBILIDADE E DENSIDADE COMO PREMISSAS DA CIDADE COMPACTA}

Aliados ao urgente incentivo à construção de novas centralidades - visão de cidade presente em planos urbanísticos paulistanos desde as décadas de 1950 e 1960 - as premissas da cidade compacta estão claramente expressas no PDE de 2014 e buscam proporcionar transformações urbanas tanto em escala local quanto reorganizar os padrões de crescimento da metrópole, direcionando as áreas de expansão urbana para o interior da área urbanizada.

\footnotetext{
${ }^{6}$ Dinâmica é denominada na geografia como disjunção produtiva, ou seja, processo pelo qual as indústrias deixaram gradativamente o centro da metrópole para se instalarem ao longo dos eixos rodoviários e pólos aeroviários no interior paulista, construindo uma nova rede produtiva altamente dinâmica. Pesquisa extensa sobre o tema em: SPOSITO, E. O novo mapa da indústria no início do século XXI. Diferentes paradigmas para a leitura das dinâmicas territoriais do Estado de São Paulo. São Paulo: Editora UNESP, 2015.
} 
Aprofundando as pesquisas empíricas, muitos trabalhos recentes buscam não somente comparar os gradientes de densidade entre diversas cidades, mas também investigar os níveis de compactação da mancha urbana em função de diversos aspectos, como a mobilidade urbana. $O$ trabalho de Angel et. al (2016), citado anteriormente, determina que a compacidade refere-se prioritariamente a uma condição morfológica e tem estreita relação com os deslocamentos intraurbanos: uma mancha urbana mais compacta minimiza a distância média de qualquer ponto da cidade até seu centro de empregos, ou ainda, reduz a distância média entre qualquer ponto da área urbanizada (ANGEL, S. et al, 2016: p.28). Para o autor, a compacidade é uma expressão bidimensional da área urbanizada e, dessa maneira, estabelece um vínculo mais forte com a acessibilidade urbana do que com a densidade propriamente dita. Assim sendo, a mancha urbana é considerada mais compacta na medida em que se aproxima de um circulo perfeito, justamente porque a forma tende a maximizar o acesso tanto ao centro de empregos, no caso de cidades monocêntricas, quanto a todas as demais localidades em cidades policêntricas (ANGEL, S. et al, 2016: p.31).

A acessibilidade e a densidade são os dois temas fundamentais no debate da cidade compacta. No modelo de Alonso-Muth-Mills (AMM), a proximidade em relação ao centro de empregos leva a menores custos de deslocamento e, por isso, pressupõe-se que nessas áreas o uso do solo será mais intenso, com unidades residenciais menores e em maior número, o que acarretará em densidades superiores. Por outro lado, nas bordas da cidade, o alto custo relativo ao transporte leva a uma terra proporcionalmente mais barata e, nesse caso, se indivíduos de alta renda ali se instalarem, é intuitivo dizer que terão acesso a residências maiores, consumindo mais terra. Nessa equação, faz sentido pensar que a redução generalizada do custo de transporte em toda a cidade teria como efeito o aumento da atratividade de áreas mais distantes do centro, resultando na valorização da terra nas bordas da cidade e, portanto, na ampliação da mancha urbana sobre as áreas rurais (BRUECKNER, 2011: p.47).

Ademais, é interessante notar que o modelo pressupõe uma infraestrutura de mobilidade distribuída de forma homogênea no território, ou seja, qualquer ponto na cidade mantém, em princípio, as mesmas propriedades e qualidades quanto a sua acessibilidade. Sabemos, no entanto, que a distribuição das redes de transporte público de alta capacidade nas cidades, responsáveis por suportar parte significativa do conjunto de deslocamentos em áreas metropolitanas, não é uniforme, desenhando gradientes variados de acessibilidade e provocando diferenciações significativas no valor do solo?

Em casos como São Paulo, essa diferenciação ganha contornos ainda mais críticos, dado que a rede apresenta limitações quanto a sua extensão e encontra-se majoritariamente concentrada no Centro Expandido ${ }^{8}$. Dessa forma, ainda que fosse possível estender a mancha urbana para acomodar a demanda por moradia, as melhores localizações - provenientes das áreas com maior acessibilidade - são extremamente limitadas, reverberando uma renda do solo desproporcionalmente alta em poucos trechos.

Uma possível solução a este dilema foi proposta no Plano Integrado de Transportes Urbanos com horizonte para implantação no ano de 2020 (PITU 2020) ${ }^{9}$ : tratava-se da construção de uma rede abrangente que alcançava as periferias metropolitanas e conectava centralidades já consolidadas. A chave para a questão não era a simples expansão da rede, mas estreitar o vínculo entre o sistema de transporte de massa e as áreas com oferta de emprego. Tal relação é fundamental, pois é possível deduzir, a partir do modelo AMM, que concentrar as ações somente na ampliação da rede não levaria a uma redução do custo de deslocamento. Isso porque se os empregos permanecem concentrados em poucos pontos da região metropolitana e distantes dos ramais periféricos da rede, ainda estaremos onerando o tempo diário gasto nos movimentos pendulares, resultando em um custo elevado de deslocamento para o usuário.

As implicações do conceito de cidade compacta para São Paulo tornam-se relevantes se pensarmos que as áreas com alta acessibilidade e grande oferta de emprego e equipamentos também apresentam baixas densidades em vários setores, sobretudo por conta de glebas vazias. O potencial urbanístico da vacância

\footnotetext{
${ }^{7}$ Para uma revisão detalhada desse tema, ver: DÉAK, C. Localização e Espaço: Valor de Uso e Valor. In: À busca das categorias de produção do espaço. FAUUSP, São Paulo, 2001 Cap. 5; VILLAÇA, F. Direções de expansão urbana. In: Espaço Intraurbano no Brasil. São Paulo: Nobel, 2001. Cap. 4.

${ }^{8}$ Para um debate a respeito das redes de mobilidade paulistanas e as premissas urbanísticas dos planos de mobilidade recentes, ver: LONGO, M. Estratégias correlatas nos planos urbanísticos e de mobilidade. In: Hubs de mobilidade e projeto urbano: ações urbanísticas e infraestrutura de transporte na metrópole de São Paulo. FAUUSP, São Paulo, 2015. Cap. 3

${ }^{9} \mathrm{O}$ PITU 2020 foi posteriormente revisado por um novo plano, o PITU 2025, atualmente em vigor mas que também sofreu adaptações para o desenho da rede atual, denominada Rede 2030.
} 
hoje encontrada em áreas próximas ao Centro, como o Arco Tietê, se dá por dois motivos principais: primeiro, o fato da área ter uma boa infraestrutura de transporte, fator positivo para suportar o aumento da densidade populacional; segundo, como veremos mais adiante, a forma de distribuição e caracterização da vacância, com presença marcante de lotes e glebas passíveis de parcelamento do solo e transformação de uso, ou seja, capazes de gerar tecido urbano qualificado, vinculando alta densidade, mistura de usos e a oferta de áreas livres.

\section{METODOLOGIA DE DEMARCAÇÃO DOS TERRITÓRIOS DE PROJETO URBANO}

Uma rápida leitura do tecido urbano atual do Arco Tietê pode confirmar a expressiva presença de áreas vazias. Não por acaso, é possível verificar a incidência de produtos imobiliários não só no Arco Tietê mas em toda a MEM, cujas tipologias dependem fortemente da existência de lotes de grande dimensão, como é o caso dos condomínios verticais multifamiliares. Por outro lado, é uma preocupação deste trabalho que a vacância não seja unicamente a somatória das áreas aparentemente vazias, mas a conjunção de uma série de condições urbanas que apontam para áreas prioritárias de transformação. Especificamente neste artigo, buscamos construir o dado de vacância a partir de duas informações fundamentais: a análise morfológica e de uso do solo, bem como os recortes, zonas e instrumentos colocados pela legislação urbanística recentemente aprovada, tais como o PDE de 2014, citado anteriormente, a Lei de Parcelamento, Uso e Ocupação do Solo (LPUOS, Lei 16.402/2016) e decretos correlatos.

A dimensão das áreas analisadas tem como premissa que as transformações e projetos pretendidos dizem respeito a escala urbana e, desta forma, não foi analisada a vacância proveniente de imóveis consolidados. Ou seja, buscamos dar preferência para lotes ${ }^{10}$ com grandes áreas, ou então para lotes menores que possam ser utilizados em conjunto, viabilizando projetos de maior porte.

O primeiro dado de análise diz respeito aos lotes notificados pelo Parcelamento, Edificação e Utilização Compulsórios (PEUC) (Figura 03), instrumento presente no PDE e que tem por objetivo garantir a função social da propriedade, ou seja, o interesse coletivo em áreas com boa oferta de infraestrutura. O PEUC notificou lotes enquadrados nas seguintes categorias: lotes não edificados (com área superior a $250 \mathrm{~m}^{2} \mathrm{e}$ Coeficiente de Aproveitamento, $C A=0$ ), lotes subutilizados (também superiores a $250 \mathrm{~m}^{2}$ e com CA menor que o mínimo exigido por lei), além de edifícios subutilizados (que permanecem $80 \%$ desocupados nos últimos 5 anos). Para o estudo, foram consideradas as duas primeiras categorias, com ênfase em lotes que possam ser agrupados, formando terrenos maiores.

Na sequência, foram somadas as áreas coincidentes com Zonas Especiais de Interesse Social (ZEIS) ${ }^{11}$ dos tipos 2, 3 e 5, de acordo com a LPUOS de 2016 (Figura 04). O PDE conceitua as ZEIS 2 como lotes ou glebas não edificadas ou subutilizadas nos quais é exigida a produção de pelo menos $80 \%$ de habitação de interesse social (HIS) e no máximo de $20 \%$ de habitação de mercado popular (HMP) e usos não residenciais ${ }^{12}$. As ZEIS 3 correspondem a edifícios ociosos ou subutilizados na área central e, no caso específico do Arco Tietê, chegam a ocupar quadras inteiras. Já a ZEIS 5 trata dos mesmos lotes das ZEIS 2, mas com foco em áreas dotadas de serviços, equipamentos e infraestrutura urbana, exigindo contudo uma proporção mínima de $40 \%$ de HIS dos tipos 1 e 2 e não oferecendo restrições para HMP.

Pela similaridade de critérios podemos claramente notar a coincidência de parte dos lotes notificados pelo PEUC com as ZEIS 2, 3 e 5, sendo que os primeiros concentram-se principalmente na porção sul do rio Tietê, nas áreas próximas ao Centro.

\footnotetext{
${ }^{10} \mathrm{~A}$ base oficial de lotes não está disponível em arquivos georreferenciados no banco de dados de São Paulo, o Geosampa. Por isso, foi feito um cruzamento entre as parcelas do Mapa Digital da Cidade e as informações das Quadras Fiscais, que contem os dados oficiais dos Setores, Quadras e Lotes do município.

11 De acordo com o Art. 12 da LPUOS, ZEIS áreas destinadas "(...) à moradia digna para a população de baixa renda por intermédio de melhorias urbanísticas, recuperação ambiental e regularização fundiária de assentamentos precários e irregulares, bem como à provisão de novas Habitações de Interesse Social e Habitações de Mercado Popular, a serem dotadas de equipamentos sociais, infraestrutura, áreas verdes e comércio e serviços locais, situadas na zona urbana".

12 HIS 1 destina-se a pessoas com renda familiar menor que 3 salários mínimos, HIS 2 menor que 6 salários mínimos e HMP menor que 10 salários mínimos.
} 


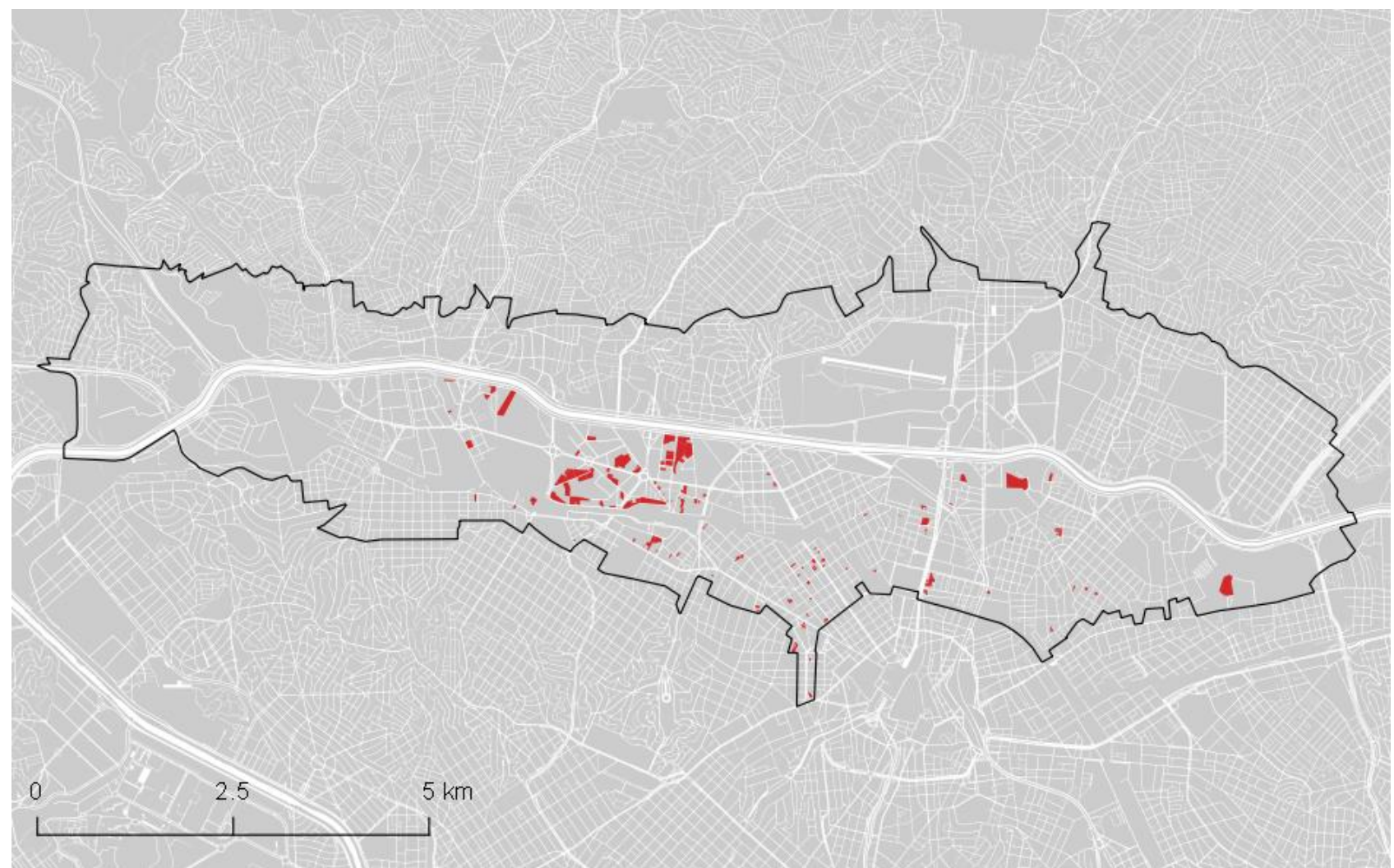

Figura 03: Imóveis notificados pelo Parcelamento, Edificação e Utilização Compulsórios (PEUC).

Fonte: Imagem do autor, dados PMSP, 2017

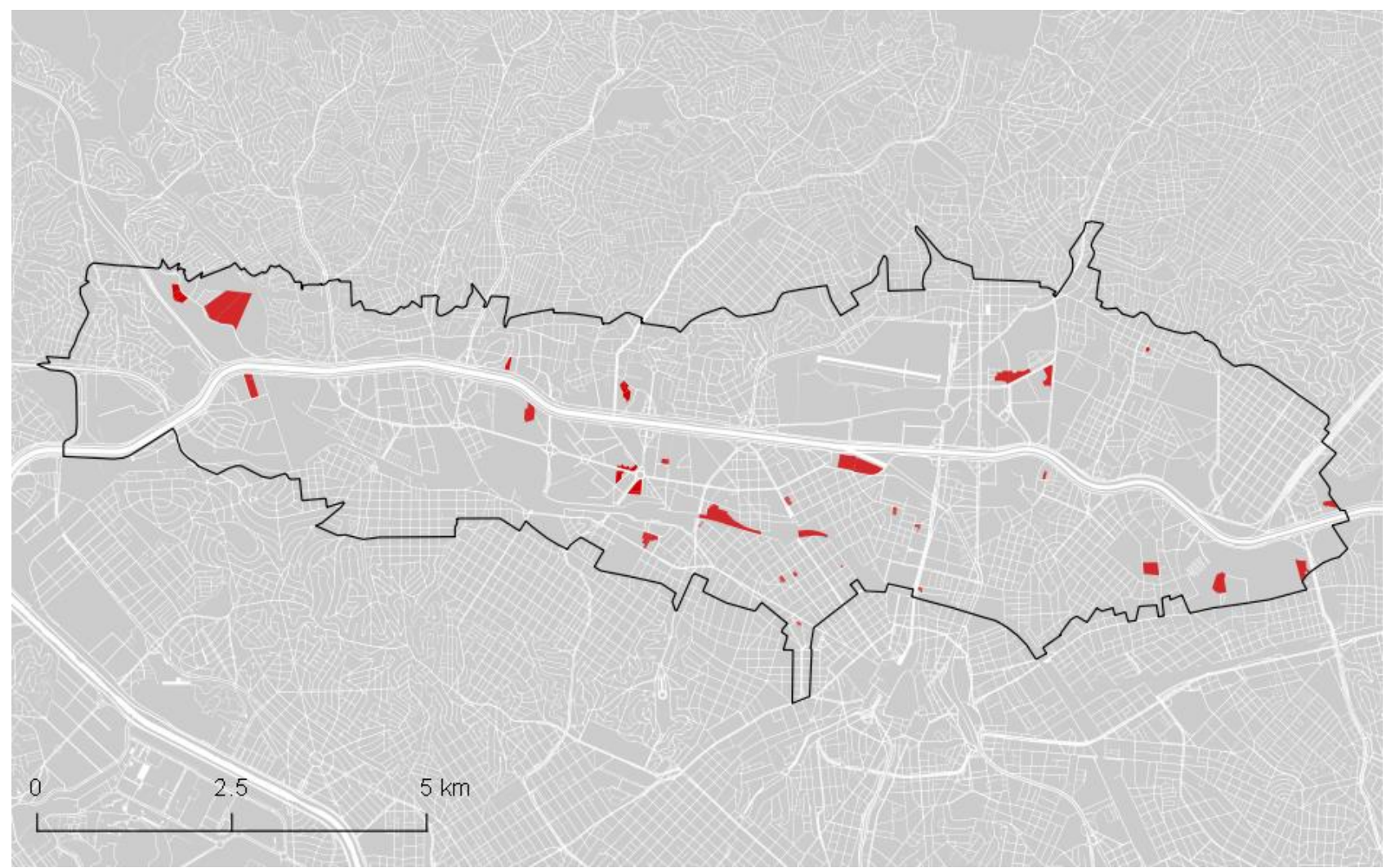

Figura 04: ZEIS 2, 3 e 5.

Fonte: Imagem do autor, dados PMSP, 2017 
Seguindo, foi feito um levantamento de todos os lotes com área superior a $20.000 \mathrm{~m}^{2}$ (Figura 05). De acordo com a LPUOS, lotes superiores a essas dimensões e submetidos a aprovação de projetos imobiliários deverão sofrer parcelamento do solo, com a devida destinação de um percentual de área pública. Tal proporção chega a no mínimo $30 \%$ (5\% de área verde, $5 \%$ de área institucional, e $20 \%$ de área sem afetação previamente definida ${ }^{13}$ ) para lotes acima de $20.000 \mathrm{~m}^{2}$ e no mínimo $40 \%$ para lotes acima de $40.000 \mathrm{~m}^{2}(10 \%$ de área verde, $5 \%$ de área institucional, $15 \%$ de sistema viário e $10 \%$ pra área sem afetação).

Dentro desse critério, chama atenção a distribuição das glebas, dispersas por quase todo o perímetro do Arco Tietê. Obviamente, tal fato decorre do padrão morfológico típico de formação da área, em função das tipologias industriais. Tardiamente, vários setores do Arco Tietê também foram ocupados por usos extensivos do solo e ligados a logística, hipermercados e comércio atacadista, reiterando o padrão anterior de lotes.

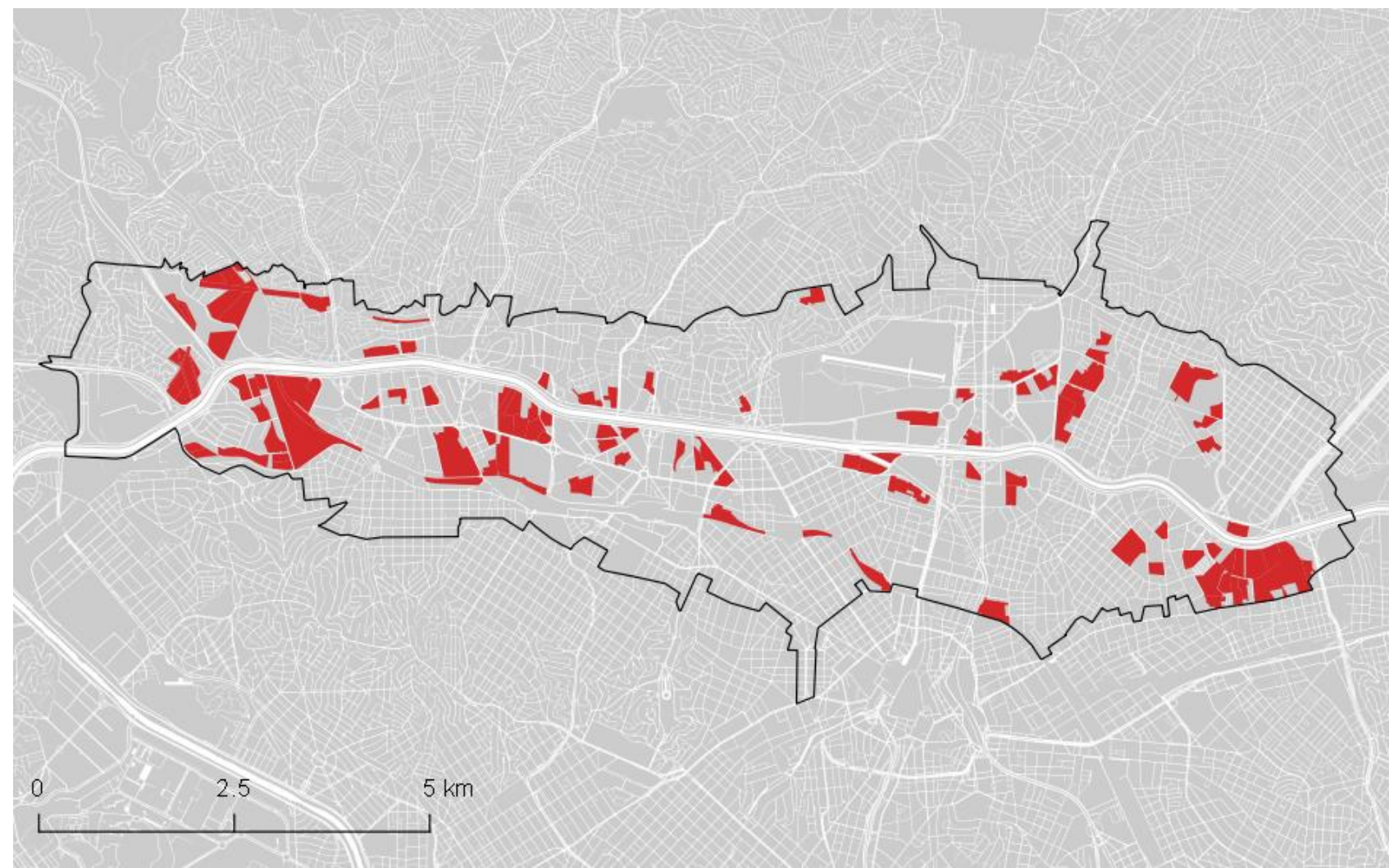

Figura 05: Lotes com mais de $20.000 \mathrm{~m}^{2}$ e $40.000 \mathrm{~m}^{2}$.

Fonte: Imagem do autor, dados PMSP, 2017

Por fim, foi realizado o levantamento do uso predominante do solo por quadra a fim de verificar eventuais trechos considerados sem uso e não assinalados nos critérios anteriores (Figura 06). Esse último passo coincidiu com uma análise cuidadosa de todos os lotes e glebas eleitos, a fim de filtrar eventuais discrepâncias. De acordo com as análises, vários lotes identificados já apresentavam edificações consolidadas, em construção, ou então já era possível notar a preparação de canteiro de obras. Verificou-se também a coincidência com clubes e áreas definidas como Zonas Especiais de Proteção Ambiental (ZEPAM), perímetros nos quais existem restrições para desenvolvimento imobiliário. Todos os lotes enquadrados nessas situações foram eliminados da amostra.

Já no caso de lotes ocupados por indústrias, verificou-se qual a postura do zoneamento: se incluídos em zonas de uso misto, intuímos que existe uma tendência de transformação e substituição funcional sinalizada pelo município e, assim, o lote continuou na amostra. Cabe destacar também, no caso de imóveis em ZEIS 3 , foram considerados somente aqueles simultaneamente notificados pelo PEUC ou passíveis de parcelamento. Isso porque, como na grande maioria corresponde a imóveis já existentes e passíveis de reforma, não seria possível ter acesso às informações de vacância para simulação posterior da densidade.

\footnotetext{
${ }^{13}$ Área sem afetação são porções que se converterão em qualquer uma das áreas públicas (verde, institucional e sistema viário), de
} acordo com as carências a região onde o lote ou gleba esteja localizado. A destinação é definida pelo poder público municipal. 


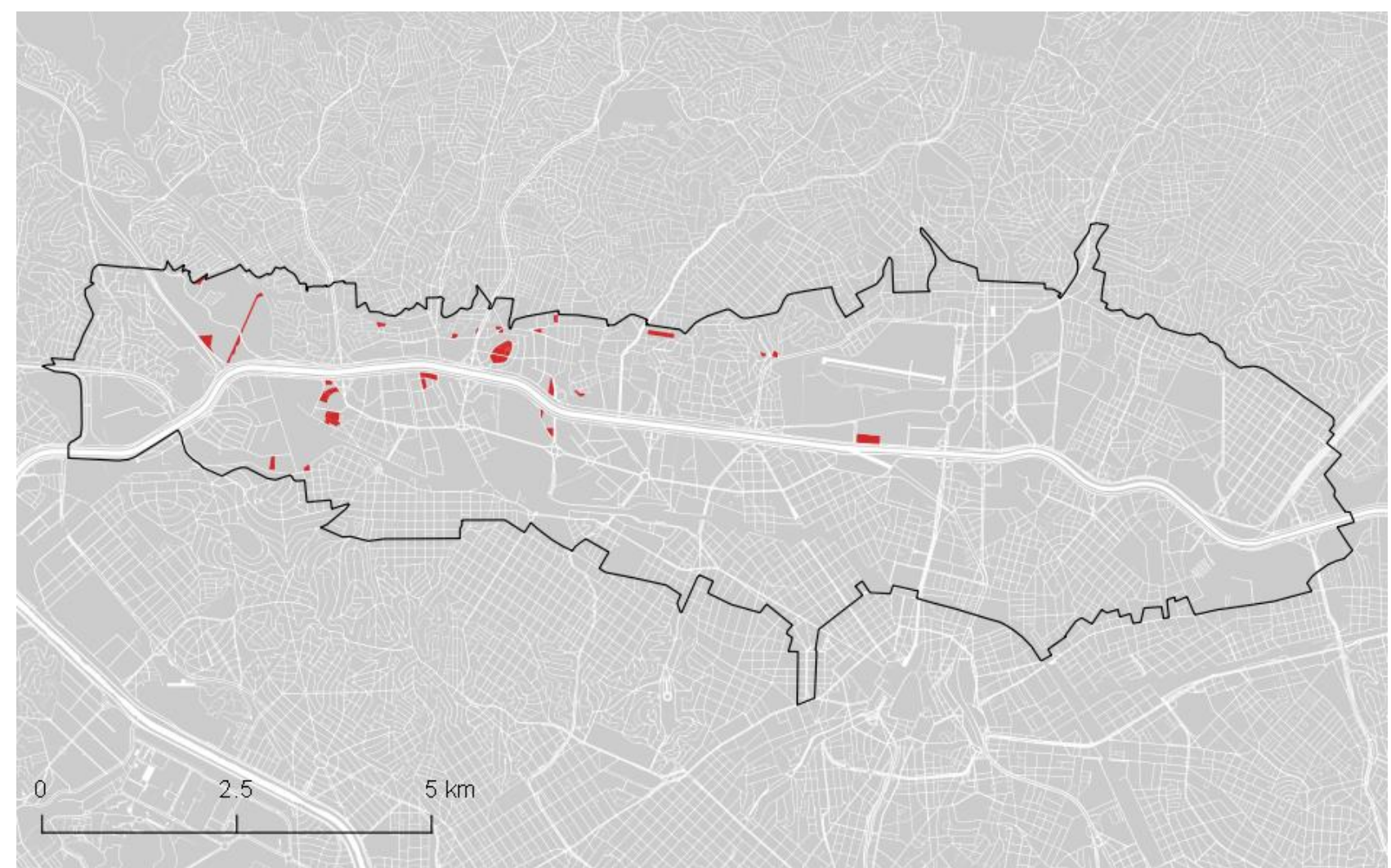

Figura 06: Áreas vazias e sem incidência de instrumentos urbanísticos.

Fonte: Imagem do autor, dados EMPLASA, 2015

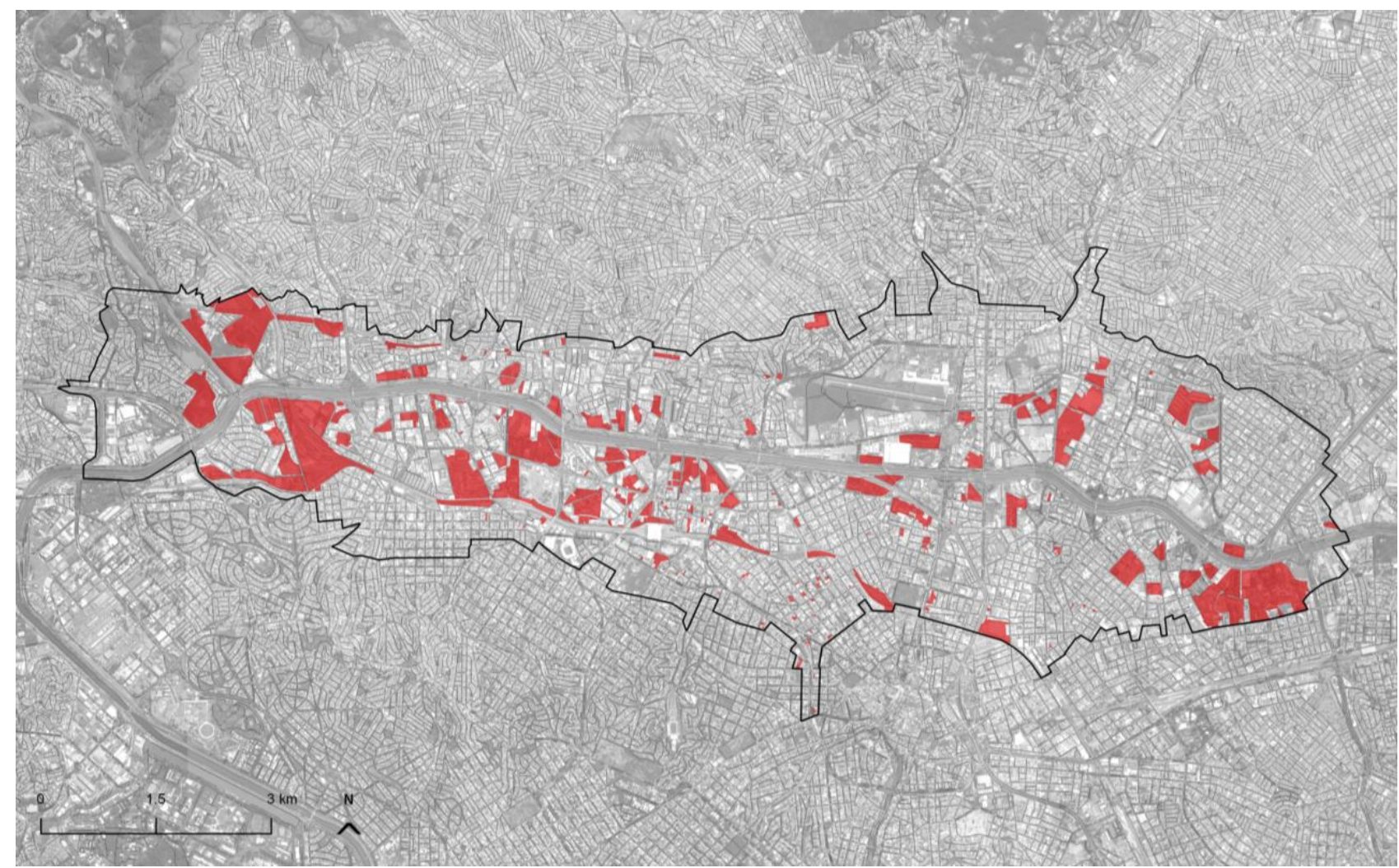

Figura 07: Conjunto final de áreas passíveis de transformação, selecionadas no Arco Tietê

Fonte: Imagem do autor. 
Com esse quadro, chegamos ao conjunto final de lotes e glebas que compõe parte da vacância - ou áreas passíveis de transformação urbana - do Arco Tietê (Figura 07). Todas as áreas somam 642,77ha e correspondem a aproximadamente $12 \%$ do perímetro, evidenciando a importância estratégica desse setor para a metrópole. É com base nessas áreas que foi simulado, na seqüência, o potencial construtivo gerado e, a partir dele, estimado o ganho habitacional e a variação de densidade populacional no Arco Tietê.

\section{ANALISE DAS ÁREAS SELECIONADAS}

O conjunto delimitado corresponde a uma amostra expressiva da MEM, em especial em relação aos setores coincidentes com a orla ferroviária e fluvial, o que demonstra um vínculo coerente entre análise e proposição promovido pelas revisões recentes do marco legal municipal de São Paulo, especialmente por conta dos instrumentos urbanísticos previstos pelo PDE e pela LPUOS.

Dos instrumentos levantados, é possível dividir aqueles capazes de promover ações diretas e a curto e médio prazos, e outros que circunscrevem parâmetros e restrições por meio dos quais pretendem direcionar determinadas visões ou modelos de cidade, com viabilidade de longo prazo. No primeiro caso enquadra-se o PEUC, visto que a partir da notificação da prefeitura, o proprietário deve cumprir uma série de prazos para reativar o imóvel, caso contrário são previstas sanções como a aplicação do IPTU progressivo no tempo ou até mesmo, em casos extremos, a desapropriação do imóvel. Já no outro polo, estão as ZEIS e a exigência de parcelamento em grandes lotes, pois não apresentam mecanismos automáticos de aplicação: em ambos os casos, é preciso interesse do proprietário em promover um empreendimento imobiliário. Somente a partir disso é exigido o cumprimento dos parâmetros previstos em lei, como a proporção mínima de HIS e HMP em ZEIS, a doação de áreas públicas e restrições na dimensão de quadras, no caso do parcelamento do solo.

Como pode ser visto na Tabela 02 a seguir, apenas uma pequena área apresenta a simultaneidade de instrumentos de ação direta e de restrição, correspondendo a menos de $3 \%$ do conjunto demarcado e a cerca de $0,35 \%$ de todo o Arco Tietê. Isso se deve, primeiramente, a estratégia de demarcação do PEUC, que priorizou a região central e áreas que já tenham operações urbanas em vigor.

Por outro lado, chama a atenção o volume de áreas com obrigatoriedade de parcelamento, atingindo próximo a $88 \%$ do conjunto levantado, reforçando o argumento de que o potencial urbanístico do setor se dá pela oportunidade de redesenho do tecido urbano. Ademais, em mais de $70 \%$ das glebas (ou cerca de $9 \%$ do Arco Tietê) essa é a única exigência, ou seja, não existem outras restrições promovidas pelos demais instrumentos urbanísticos.

\begin{tabular}{|c|c|c|c|c|c|c|}
\hline ZEIS 2, 3 E 5 & PEUC & PARCELAMENTO & $\begin{array}{l}\text { SEM USO E SEM } \\
\text { INCIDÊNCIA }\end{array}$ & \multirow{2}{*}{$\begin{array}{l}\text { ÁREA } \\
\text { (ha) }\end{array}$} & \multirow{2}{*}{$\begin{array}{c}\% \text { DAS } \\
\text { AREAS } \\
\text { MARCADAS }\end{array}$} & \multirow{2}{*}{$\begin{array}{c}\% \text { DO } \\
\text { ARCO TIETÉ }\end{array}$} \\
\hline \multirow[t]{9}{*}{74,52 ha } & 53,11 ha & 565,49 ha & 25,93 ha & & & \\
\hline & & & & 3,40 & $0,52 \%$ & $0,06 \%$ \\
\hline & & & & 3,46 & $0,53 \%$ & $0,06 \%$ \\
\hline & & & & 54,05 & $8,27 \%$ & $1,00 \%$ \\
\hline & & & & 13,60 & $2,08 \%$ & $0,25 \%$ \\
\hline & & & & 11,96 & $1,83 \%$ & $0,22 \%$ \\
\hline & & & & 34,29 & $5,24 \%$ & $0,64 \%$ \\
\hline & & & & 496,07 & $77,18 \%$ & $9,22 \%$ \\
\hline & & & & 25,93 & $3,96 \%$ & $0,48 \%$ \\
\hline \multicolumn{4}{|c|}{ TOTAL } & 642,77 & $100,00 \%$ & $11,95 \%$ \\
\hline
\end{tabular}

Tabela 02: Distribuição das áreas e incidência das características levantadas.

Já nas análises de predominância de uso, constatou-se que aproximadamente $4 \%$ das áreas levantadas não foram atingidas por qualquer um dos instrumentos urbanísticos, correspondendo a um volume similar a quase 26 quadras.

Como o objetivo central deste trabalho é debater a possibilidade de expansão intraurbana, favorecendo a consolidação de trechos mais compactos e densos de cidade, utilizamos os dados acima para estimar qual 
o impacto na densidade populacional se fosse priorizada a ocupação das áreas ociosas, com foco na produção de unidades habitacionais. A metodologia utilizada, no campo do urbanismo, guarda muitas similares com as estratégias no campo da economia, na medida em que eliminaremos algumas variáveis para nos aproximarmos a uma ordem de grandeza do volume de novos moradores atraídos.

Seria possível, a partir do levantamento realizado, fazemos uma estimativa geral a partir de um cálculo único considerando toda a somatória de áreas. No extremo oposto, muitas etapas adiante, um resultado mais preciso dependeria do desenho e de simulações tipológicas em cada lote ou gleba, isso porque somente com tais procedimentos conseguiríamos ter certeza de que os números produzidos tem como base loteamentos bem estruturados, edifícios bem implantados, conectividade no sistema viário, etc. Seria possível, inclusive, incorporar todas as demais restrições urbanísticas e ambientais que evidentemente existem.

Optou-se aqui por considerar uma situação intermediária, na qual são incluídas proporções gerais decorrentes de experiências de projeto e as restrições da área em função da LPUOS e do PDE. Com base nesse método, foi necessária a determinação de alguns parâmetros mínimos a serem aplicados aos lotes e glebas:

- No parcelamento de áreas entre $20.000 \mathrm{~m}^{2}$ e $40.000 \mathrm{~m}^{2}$, a proporção de doação de área pública seguiu a exigência de $30 \%$ e, como não foi considerada a existência de sistema viário, o percentual foi distribuído entre as Áreas Verdes e Institucionais;

- No parcelamento de áreas superiores a $40.000 \mathrm{~m}^{2}$, foi considerada uma doação de $45 \%$ de área pública, ou seja, superior a exigida de $40 \%$ pela lei. Isso porque a média de sistema viário produzido em loteamentos dificilmente ficará abaixo de $20 \%$ (contra os $15 \%$ da lei). Desta forma, mantiveram-se $5 \%$ de Áreas Institucionais, $20 \%$ de sistema viário e $20 \%$ de área verde (que passa a contemplar as áreas sem afetação);

- $\quad$ Em áreas de ZEIS 2 e 3, considerou-se 80\% da área privada em HIS, distribuindo o restante em HMP e demais usos não residenciais, que devem atingir no máximo $20 \%$;

- $\quad$ Em áreas de ZEIS 5, considerou-se a exigência de 40\% de HIS. Nos demais usos, considerou-se $40 \%$ de HMP, $10 \%$ de habitação multifamiliar de padrão médio e $10 \%$ de usos não residenciais (por lei, a soma dos 2 últimos não pode ultrapassar $40 \%$ );

- Nas demais zonas, as habitações foram distribuídas da seguinte forma: 10\% multifamiliar de alto padrão, $35 \%$ de médio padrão, $40 \%$ HMP e $15 \%$ HIS;

- Na Zona de Centralidade (ZC) e nas Zonas de Desenvolvimento Econômico 1 e 2 (ZDE1 e 2), consideramos a proporção de $30 \%$ de área residencial e $70 \%$ de área não residencial devido a vocação prevista pelo zoneamento;

- $\quad$ Na Zona Mista (ZM), Zona de Estruturação Metropolitana (ZEM), Zona de Estruturação Metropolitana Prevista (ZEMP) e Zona de Ocupação Especial (ZOE), utilizamos a proporção de $80 \%$ de área residencial e $20 \%$ de área não residencial, dado que pretendemos ampliar o número de residentes e que o volume de empregos no setor já é significativo;

- Utilizamos o CAmáx de 4 para as ZEIS 2, 3 e 5, considerando as restrições: CA máximo = 2 em lotes $<1000 \mathrm{~m}^{2}$ para ZEIS 2 e 5 , bem como para lotes $<500 \mathrm{~m}^{2}$ em ZEIS 3 ;

- $\quad$ Em ZC, ZM, ZDE1, ZDE2, ZEM, ZEMP e ZOE foi utilizado CA máximo = 2. Seria possível utilizar CA máximo maiores para as três últimas zonas, mas isso exigiria simulações projetuais dos empreendimentos, que não é foco desse estudo;

- Áreas médias para unidades habitacionais multifamiliares (UH): $150 \mathrm{~m}^{2}$ (alto padrão), $100 \mathrm{~m}^{2}$ (médio padrão), $70 \mathrm{~m}^{2}$ (HMP), $60 \mathrm{~m}^{2}$ (HIS);

- Considerou-se a proporção de 2,8 habitantes/UH em edifícios de alto e médio padrão e 3,2 em HMP e HIS. 
Tais parâmetros foram calibrados em função de $\mathbf{1 0}$ empreendimentos-tipo identificados a partir da incidência das restrições urbanísticas (ver Anexo). Ao final, com a somatória de todas as Unidades Habitações produzidas pelos variados empreendimentos, foi possível chegar no número estimado de acréscimo populacional, contabilizando mais de 300 mil pessoas e uma densidade populacional bruta de 121,73 habitantes/ha (Tabela 03).

\begin{tabular}{ll}
\hline Área Total - Arco Tietê & 5380,35 ha \\
\hline Área dos lotes e glebas & $\mathbf{6 4 2 , 7 7}$ ha (11,95\%) \\
\hline Área institucional (pública) gerada & 37,84 ha \\
\hline Área verde (pública) gerada & 113,10 ha \\
\hline População atual (CENSO 2010) & 342.944 pessoas \\
\hline Acréscimo populacional & $\mathbf{3 1 2 . 0 2 1}$ pessoas (+90,98\%) \\
\hline Unidades habitacionais & $\mathbf{1 0 0 . 5 4 1}$ unidades \\
\hline Densidade populacional bruta atual & 63,74 hab/ha \\
\hline Densidade populacional bruta futura & $\mathbf{1 2 1 , 7 3 ~ h a b / h a}$ \\
\hline
\end{tabular}

Tabela 03: Resumo das estimativas urbanísticas.

Considerando os dados relativos ao CENSO 2010, que apontava uma densidade bruta de pouco mais de 63 habitantes/ha - uma densidade muito baixa, inclusive menor que a densidade média da cidade São Paulo, que gira em torno 72 habitantes/ha (SMDU, 2014) - é expressiva informação de que a ocupação de quase $12 \%$ do território do Arco Tietê poderia quase dobrar sua densidade bruta. Ainda assim, analisando a presença das redes de transporte de alta e média capacidade e a facilidade de acesso a empregos e serviços dentro do perímetro e no seu entorno, é possível afirmar que se trata de uma densidade relativamente baixa, sendo que diversos pontos do próprio Arco Tietê apresentam hoje densidades significativamente superiores (213 habitantes/ha em Santa Cecília, por exemplo, segundo dados da SMDU, 2014) $)^{14}$.

Já o número de unidades habitacionais produzidas representa pouco menos de $15 \%$ do déficit habitacional da metrópole de São Paulo ${ }^{15}$. Dentro desse número, 37.393 (ou 37\%) correspondem a HIS, demonstrando que existe grande margem para produção habitacional próximo as áreas centrais, garantida pela legislação urbanística em vigor: estratégia essa que corrobora com as noções de cidade compacta e expansão intraurbana analisadas anteriormente.

\section{CONCLUSÕES}

Este trabalho buscou explorar alternativas para incentivar a expansão intraurbana na metrópole de São Paulo em uma área com ótima oferta de infraestrutura e com alto grau de ociosidade. Para tanto, trabalhamos os conceitos de urbanização extensiva e de cidade compacta, ambos frequentemente correlacionados, sobretudo a partir da intensificação do processo de crescimento da área urbanizada e os problemas decorrentes em diversas metrópoles. Abordamos tais temas tendo como foco um território específico da metrópole de São Paulo, o Arco Tietê, cuja caracterização urbanística revela não só uma vocação metropolitana, mas a presença de áreas estratégicas para projeto urbano.

As análises empíricas demonstraram que existe um estoque significativo de terras ao longo do perímetro do Arco Tietê atingido por uma série de instrumentos e determinações urbanísticas recentes. Ademais, buscamos demonstrar que a ativação de tais instrumentos é um fato decisivo para o incentivo ao adensamento urbano, na busca de alternativas ao espraiamento ainda em curso na escala metropolitana e macrometropolitana.

Um resultado importante a se considerar é a quantidade de área pública gerada pelas glebas demarcadas, contando com quase 38 ha de áreas institucionais e cerca de 113 ha de área verde (cerca de $73 \%$ da área do Parque do lbirapuera). Sabemos que as áreas públicas são geradas mediante parcelamento do solo e,

\footnotetext{
${ }^{14}$ Como referência, é possível citar a recomendação da ONU de 450 habitantes/ha.

${ }^{15}$ O déficit habitacional da RMSP em 2010 era cerca de 694,000 unidades, segundo cálculo do IPEA (2013).
} 
considerando a grande distribuição de glebas passíveis de loteamento em todo perímetro (Imagem 05), torna-se evidente o potencial de qualificação do tecido urbano.

As áreas públicas, sejam elas equipamentos ou áreas verdes, devem ser lidas em conjunto, relevando um verdadeiro sistema de espaços livres do qual não só o Arco Tietê, mas boa parte da metrópole ainda é muito carente. Do ponto de vista específico do Arco Tietê, dado que se trata de uma região de várzea, esse sistema pode ainda ter um papel complementar de infraestrutura de drenagem, atenuando os problemas crônicos de alagamento. Em relação aos sistemas de mobilidade, existe também a chance de implantação de novos modais ou a construção de conexões viárias hoje de difícil execução, principalmente pela disponibilidade de terrenos públicos.

Portanto, pelo olhar do projeto urbano, são inúmeras as possibilidades abertas e todas estão direta ou indiretamente vinculadas à necessidade de pensarmos cidades mais compactas, sobretudo a partir da análise e da interpretação das condições - e das oportunidades - urbanas existentes, tal como buscamos abordar neste trabalho.

\section{REFERÊNCIAS BIBLIOGRÁFICAS}

ANGEL, S.; PARENT, J.; CIVCO, D.; BLEI, A. Atlas of urban expansion. New York: NYU, Nairobi: UNHabitat, Cambridge: Lincoln Institute of Land Policy, 2016.

BRUECKNER, J. Lectures on Urban Economics. Cambridge: The MIT Press, 2011

BURCHFIELD, M.; OVERMAN, H.; PUGA, D.; TURNER, M. Causes of sprawl: a portrait from space. In: Quarterly Journal of Economics, May 2006.

FRANCO, F.; HELDT D'ALMEIDA, C.; ABREU, G. A Macroárea de Estruturação Metropolitana de São Paulo. O projeto urbano como instrumento de transformação do território. Revista Iberoamericana de Urbanismo, Barcelona, v.12, p. 53-74, 2015.

HERCE VALLEJO, M. Sobre la movilidad en la ciudad. Propuestas para recuperar un derecho ciudadano. Barcelona: Reverte, 2009.

GROSTEIN, M. Periferias metropolitanas em nova escala: um novo ciclo da urbanização em São Paulo. Revistalberoamericana de Urbanismo, Barcelona, v.12, p. 33-52, 2015.

GORDON, P.; RICHARDSON, H. Are Compact Cities a Desirable Planning Goal? Journal of the American Planning Association, Chicago, v. 63, n. 1, p. 95-106, 1997.

MEYER, R.; GALVÃO, R.; LONGO, M. São Paulo e suas escalas de urbanização. Cidade, metrópole e macrometrópole. Revista Iberoamericana de Urbanismo, Barcelona, v.12, p. 07-31, 2015.

MEYER, R.; GROSTEIN, M. Metrópoles Brasileiras: seus desafios urbanos e suas perspectivas. In: Pós Revista do Programa de Pós-Graduação em Arquitetura e Urbanismo da Universidade de São Paulo, n. 20, p. 34-59, Dezembro 2006

MONCLUS, J. (Ed.). La ciudad dispersa. Suburbanización y nuevas periferias. Barcelona: CCCB, 1996.

NADALLIN, V.; IGLIORI, D. Espraiamento urbano e periferização da pobreza na Região Metropolitana de São Paulo: evidências empíricas. In: Revista de Estudos Urbano Regionales, v.41, n. 124. septiembre 2015, p. 91-111, 2015

NEUMAN, M. The compact city fallacy. Journal of Planning Education and Research, Tallahassee, v.25, p. 11-26, 2005.

REIS, N. G. Notas sobre urbanização dispersa e novas formas de tecido urbano. São Paulo: Via das Artes, 2006.

SPOSITO, M. Urbanização difusa e cidades dispersas: perspectivas espaço-temporais contemporâneas. In: REIS, N. (org.). Sobre dispersão urbana. São Paulo: Via das Artes, 2009.

Lei Municipal n. 16.050 de 31 de junho de 2014. Aprova a Politica de Desenvolvimento Urbano e o Plano Diretor Estrategico do Municipio de Sao Paulo e revoga a Lei no 13.430/2002.

Lei Municipal n. 16.402 de 22 de março de 2016. Disciplina o parcelamento, o uso e a ocupação do solo no Município de São Paulo, de acordo com a Lei no 16.050, de 31 de julho de 2014 - Plano Diretor Estratégico (PDE). 


\section{ANEXO}

\begin{tabular}{|c|c|c|c|c|c|c|}
\hline \multicolumn{7}{|c|}{ EMPREENDIMENTO TIPO 1 (Parcelamento - $20.000<$ área $<40.000 \mathrm{~m}^{2}$ ) } \\
\hline & $\%$ & Área $\left(\mathrm{m}^{2}\right)$ & $\begin{array}{c}\text { Área } \\
\text { Computável } \\
\left(\mathrm{m}^{2}\right)\end{array}$ & $\begin{array}{c}\text { Área por UH } \\
\underset{\left(\mathrm{m}^{2}\right)}{ }\end{array}$ & Unidades & $\begin{array}{l}\text { População } \\
\text { equivalente }\end{array}$ \\
\hline Total & $100,0 \%$ & 1691081,87 & - & - & 23450 & 71882 \\
\hline Áreas Públicas & $30,0 \%$ & 507324,56 & - & - & - & - \\
\hline Área Institucional & $10,0 \%$ & 169108,19 & - & - & - & - \\
\hline Área Verde & $20,0 \%$ & 338216,37 & - & - & - & - \\
\hline Sistema Viário & - & - & - & - & - & - \\
\hline Área Privada - Uso Residencial & $56,0 \%$ & 947005,85 & 1894011,69 & - & - & - \\
\hline Multifamiliar de Alto Padrão $(10 \%)^{*}$ & $5,6 \%$ & 94700,58 & 189401,17 & 150,00 & 1263 & 3535 \\
\hline Multifamiliar de Médio Padrão (35\%)* & $19,6 \%$ & 331452,05 & 662904,09 & 100,00 & 6629 & 18561 \\
\hline Habitação de Mercado Popular $(40 \%)^{*}$ & $22,4 \%$ & 378802,34 & 757604,68 & 70,00 & 10823 & 34633 \\
\hline Habitação de Interesse Social (15\%)* & $8,4 \%$ & 142050,88 & 284101,75 & 60,00 & 4735 & 15152 \\
\hline Área Privada - Uso Não Residencial & $14,0 \%$ & 236751,46 & 473502,92 & - & - & - \\
\hline
\end{tabular}

*Em relação a área privada residencial

EMPREENDIMENTO TIPO 2 (Parcelamento 20.000 < área $<40.000 \mathrm{~m}^{2}$ e ZEIS 2 ou 3)

\begin{tabular}{l|c|c|c|c|c|c}
\hline & $\%$ & Área $\left(\mathrm{m}^{2}\right)$ & $\begin{array}{c}\text { Área } \\
\left(\mathrm{m}^{2}\right)\end{array}$ & $\begin{array}{c}\text { Área por } \\
\mathrm{UH}\left(\mathrm{m}^{2}\right)\end{array}$ & Unidades & $\begin{array}{c}\text { População } \\
\text { equivalente }\end{array}$ \\
\hline Total & $\mathbf{1 0 0 , 0 \%}$ & $\mathbf{1 9 7 1 8 8 , 7 3}$ & - & - & $\mathbf{8 1 5 0}$ & $\mathbf{2 6 0 8 1}$ \\
\hline Área Pública & $\mathbf{3 0 , 0 \%}$ & $\mathbf{5 9 1 5 6 , 6 2}$ & - & - & - & - \\
\hline Área Institucional & $10,0 \%$ & 19718,87 & - & - & - & - \\
\hline Área Verde & $20,0 \%$ & 39437,75 & - & - & - & - \\
\hline Sistema Viário & - & - & - & - & - & - \\
\hline Área Privada - Uso Residencial & $\mathbf{6 3 , 0 \%}$ & $\mathbf{1 2 4 2 2 8 , 9 0}$ & $\mathbf{2 4 8 4 5 7 , 8 0}$ & - & - & - \\
\hline Habitação de Mercado Popular (10\%)** & $7,0 \%$ & 13803,21 & 55212,84 & 70,00 & 789 & 2524 \\
\hline Habitação de Interesse Social (80\%)** & $56,0 \%$ & 110425,69 & 441702,76 & 60,00 & 7362 & 23557 \\
\hline Área Privada - Uso Não Residencial & $\mathbf{7 , 0 \%}$ & $\mathbf{1 3 8 0 3 , 2 1}$ & $\mathbf{2 7 6 0 6 , 4 2}$ & - & - & - \\
\hline
\end{tabular}

${ }^{* *}$ Em relação a área privada residencial e não residencial

\begin{tabular}{|c|c|c|c|c|c|c|}
\hline \multicolumn{7}{|c|}{ EMPREENDIMENTO TIPO 3 (Parcelamento $20.000<$ área $<40.000 \mathrm{~m}^{2}$ e ZEIS 5) } \\
\hline & $\%$ & Área $\left(\mathrm{m}^{2}\right)$ & $\begin{array}{c}\text { Área } \\
\text { Computável } \\
\left(\mathrm{m}^{2}\right)\end{array}$ & $\begin{array}{c}\text { Área por } \\
\mathrm{UH}\left(\mathrm{m}^{2}\right)\end{array}$ & Unidades & $\begin{array}{l}\text { População } \\
\text { equivalente }\end{array}$ \\
\hline Total & $100,0 \%$ & 24907,98 & - & - & 933 & 2958 \\
\hline Área Pública & $30,0 \%$ & 7472,39 & - & - & - & - \\
\hline Área Institucional & $10,0 \%$ & 2490,80 & - & - & - & - \\
\hline Área Verde & $20,0 \%$ & 4981,60 & - & - & - & - \\
\hline Sistema Viário & - & - & - & - & - & - \\
\hline Área Privada - Uso Residencial & $63,0 \%$ & 15692,03 & 31384,05 & - & - & - \\
\hline Multifamiliar de Médio Padrão $(10 \%)^{* *}$ & $7,0 \%$ & 1743,56 & 6974,23 & 100,00 & 70 & 195 \\
\hline Habitação de Mercado Popular (40\%) ${ }^{* *}$ & $28,0 \%$ & 6974,23 & 27896,94 & 70,00 & 399 & 1275 \\
\hline Habitação de Interesse Social $(40 \%)^{\star *}$ & $28,0 \%$ & 6974,23 & 27896,94 & 60,00 & 465 & 1488 \\
\hline Área Privada - Uso Não Residencial & $7,0 \%$ & 1743,56 & 6974,23 & - & - & - \\
\hline
\end{tabular}

**Em relação a área privada residencial e não residencial 


\begin{tabular}{|c|c|c|c|c|c|c|}
\hline \multicolumn{7}{|c|}{ EMPREENDIMENTO TIPO 4 (Parcelamento área $>40.000 \mathrm{~m}^{2}$ ) } \\
\hline & $\%$ & Área $\left(\mathrm{m}^{2}\right)$ & $\begin{array}{c}\text { Área } \\
\text { Computável } \\
\left(\mathrm{m}^{2}\right)\end{array}$ & $\begin{array}{l}\text { Área por } \\
\mathrm{UH}\left(\mathrm{m}^{2}\right)\end{array}$ & Unidades & $\begin{array}{l}\text { População } \\
\text { equivalente }\end{array}$ \\
\hline Total & $100,0 \%$ & 3389284,81 & - & - & 36927 & 113196 \\
\hline Áreas Públicas & $45,0 \%$ & 1525178,16 & - & - & - & - \\
\hline Área Institucional & $5,0 \%$ & 169464,24 & - & - & - & - \\
\hline Área Verde & $20,0 \%$ & 677856,96 & - & - & - & - \\
\hline Sistema Viário & $20,0 \%$ & - & - & - & - & - \\
\hline Área Privada - Uso Residencial & $44,0 \%$ & 1491285,32 & 2982570,63 & - & - & - \\
\hline Multifamiliar de Alto Padrão $(10 \%)^{*}$ & $4,4 \%$ & 149128,53 & 298257,06 & 150,00 & 1988 & 5567 \\
\hline Multifamiliar de Médio Padrão (35\%)* & $15,4 \%$ & 521949,86 & 1043899,72 & 100,00 & 10439 & 29229 \\
\hline Habitação de Mercado Popular (40\%)* & $17,6 \%$ & 596514,13 & 1193028,25 & 70,00 & 17043 & 54538 \\
\hline Habitação de Interesse Social $(15 \%)^{*}$ & $6,6 \%$ & 223692,80 & 447385,59 & 60,00 & 7456 & 23861 \\
\hline Área Privada - Uso Não Residencial & $11,0 \%$ & 372821,33 & 745642,66 & - & - & - \\
\hline
\end{tabular}

*Em relação a área privada residencial

\begin{tabular}{l|c|c|c|c|c|c}
\hline EMPREENDIMENTO TIPO 5 (Parcelamento área $\mathbf{4 0 . 0 0 0 \mathbf { m } ^ { 2 }}$ em ZEIS 2 ou 3) \\
\hline & $\%$ & Área $\left(\mathrm{m}^{2}\right)$ & $\begin{array}{c}\text { Área } \\
\text { Computável } \\
\left(\mathrm{m}^{2}\right)\end{array}$ & $\begin{array}{c}\text { Área por } \\
\text { UH }\left(\mathrm{m}^{2}\right)\end{array}$ & $\begin{array}{c}\text { Unidades } \\
\text { População } \\
\text { equivalente }\end{array}$ \\
\hline Total & $\mathbf{1 0 0 , 0 \%}$ & $\mathbf{1 7 1 7 3 1 , 3 4}$ & - & - & $\mathbf{5 5 7 7}$ & $\mathbf{1 7 8 4 7}$ \\
\hline Áreas Públicas & $\mathbf{4 5 , 0 \%}$ & $\mathbf{7 7 2 7 9 , 1 0}$ & - & - & - & - \\
\hline Área Institucional & $5,0 \%$ & 8586,57 & - & - & - & - \\
\hline Área Verde & $20,0 \%$ & 34346,27 & - & - & - & - \\
\hline Sistema Viário & $20,0 \%$ & - & - & - & - & - \\
\hline Área Privada - Uso Residencial & $\mathbf{4 9 , 5 \%}$ & $\mathbf{8 5 0 0 7 , 0 1}$ & $\mathbf{1 7 0 0 1 4 , 0 3}$ & - & - & - \\
\hline Habitação de Mercado Popular (10\%) & $5,5 \%$ & 9445,22 & 37780,89 & 70,00 & 540 & 1727 \\
\hline Habitação de Interesse Social (80\%) & $44,0 \%$ & 75561,79 & 302247,16 & 60,00 & 5037 & 16120 \\
\hline Área Privada - Uso Não Residencial & $\mathbf{5 , 5 \%}$ & $\mathbf{9 4 4 5 , 2 2}$ & $\mathbf{1 8 8 9 0 , 4 5}$ & - & - & - \\
\hline
\end{tabular}

${ }^{*}$ Em relação a área privada residencial e não residencial

\begin{tabular}{|c|c|c|c|c|c|c|}
\hline \multicolumn{7}{|c|}{ EMPREENDIMENTO TIPO 6 (Parcelamento área $>40.000 \mathrm{~m}^{2}$ em ZEIS 5) } \\
\hline & $\%$ & Área $\left(m^{2}\right)$ & $\begin{array}{c}\text { Área } \\
\text { Computável } \\
\left(\mathrm{m}^{2}\right)\end{array}$ & $\begin{array}{c}\text { Área por } \\
\mathrm{UH}\left(\mathrm{m}^{2}\right)\end{array}$ & Unidades & $\begin{array}{l}\text { População } \\
\text { equivalente }\end{array}$ \\
\hline Total & $100,0 \%$ & 180688,83 & - & - & 4922 & 15749 \\
\hline Áreas Públicas & $45,0 \%$ & 81309,97 & - & - & - & - \\
\hline Área Institucional & $5,0 \%$ & 9034,44 & - & - & - & - \\
\hline Área Verde & $20,0 \%$ & 36137,77 & - & - & - & - \\
\hline Sistema Viário & $20,0 \%$ & - & - & - & - & - \\
\hline Área Privada - Uso Residencial & $44,0 \%$ & 79503,09 & 159006,17 & - & - & - \\
\hline Multifamiliar de Médio Padrão $(10 \%)^{\star \star}$ & $5,5 \%$ & 9937,89 & 39751,54 & 100,00 & 398 & 1113 \\
\hline Habitação de Mercado Popular $(40 \%)^{\star \star}$ & $22,0 \%$ & 39751,54 & 159006,17 & 70,00 & 2272 & 7269 \\
\hline Habitação de Interesse Social $(40 \%)^{\star *}$ & $22,0 \%$ & 39751,54 & 159006,17 & 60,00 & 2650 & 8480 \\
\hline Área Privada - Uso Não Residencial & $11,0 \%$ & 19875,77 & 39751,54 & - & - & - \\
\hline
\end{tabular}

\footnotetext{
**Em relação a área privada residencial e não residencial
} 


\begin{tabular}{|c|c|c|c|c|c|c|}
\hline \multicolumn{7}{|c|}{ EMPREENDIMENTO TIPO 7 (Lotes em ZM, ZEM, ZEMP, ZOE) } \\
\hline & $\%$ & Área $\left(m^{2}\right)$ & $\begin{array}{c}\text { Área } \\
\text { Computável } \\
\left(\mathrm{m}^{2}\right)\end{array}$ & $\begin{array}{c}\text { Área por } \\
\mathrm{UH}\left(\mathrm{m}^{2}\right)\end{array}$ & Unidades & $\begin{array}{l}\text { População } \\
\text { equivalente }\end{array}$ \\
\hline Total & $100,0 \%$ & 514038,41 & - & - & 10183 & 31214 \\
\hline Área Privada - Uso Residencial & $80,0 \%$ & 411230,73 & 822461,46 & - & - & - \\
\hline Multifamiliar de Alto Padrão $(10 \%)^{*}$ & $8,0 \%$ & 41123,07 & 82246,15 & 150,00 & 548 & 1535 \\
\hline Multifamiliar de Médio Padrão (35\%)* & $28,0 \%$ & 143930,75 & 287861,51 & 100,00 & 2879 & 8060 \\
\hline Habitação de Mercado Popular (40\%)* & $32,0 \%$ & 164492,29 & 328984,58 & 70,00 & 4700 & 15039 \\
\hline Habitação de Interesse Social (15\%)* & $12,0 \%$ & 61684,61 & 123369,22 & 60,00 & 2056 & 6580 \\
\hline Área Privada - Uso Não Residencial & $20,0 \%$ & 102807,68 & 205615,36 & - & - & - \\
\hline
\end{tabular}

\begin{tabular}{l|c|c|c|c|c|c}
\hline EMPREENDIMENTO TIPO 8 (Lotes em ZC, ZDE1, ZDE2) \\
\hline & $\%$ & Área $\left(\mathrm{m}^{2}\right)$ & $\begin{array}{c}\text { Área } \\
\text { Computável } \\
\left(\mathrm{m}^{2}\right)\end{array}$ & $\begin{array}{c}\text { Área por } \\
\text { UH }\left(\mathrm{m}^{2}\right)\end{array}$ & Unidades & $\begin{array}{c}\text { População } \\
\text { equivalente }\end{array}$ \\
\hline Total & $\mathbf{1 0 0 , 0 \%}$ & $\mathbf{8 8 1 6 2 , 7 2}$ & - & - & $\mathbf{6 5 5}$ & $\mathbf{2 0 0 8}$ \\
\hline Área Privada - Uso Residencial & $\mathbf{3 0 , 0 \%}$ & $\mathbf{2 6 4 4 8 , 8 2}$ & $\mathbf{5 2 8 9 7 , 6 3}$ & - & - & - \\
\hline Multifamiliar de Alto Padrão (10\%)* & $3,0 \%$ & 2644,88 & 5289,76 & 150,00 & 35 & 99 \\
\hline Multifamiliar de Médio Padrão (35\%)* & $10,5 \%$ & 9257,09 & 18514,17 & 100,00 & 185 & 518 \\
\hline Habitação de Mercado Popular (40\%) & $12,0 \%$ & 10579,53 & 21159,05 & 70,00 & 302 & 967 \\
\hline Habitação de Interesse Social (15\%)* & $4,5 \%$ & 3967,32 & 7934,64 & 60,00 & 132 & 423 \\
\hline Área Privada - Uso Não Residencial & $\mathbf{7 0 , 0 \%}$ & $\mathbf{6 1 7 1 3 , 9 0}$ & $\mathbf{1 2 3 4 2 7 , 8 1}$ & - & - & - \\
\hline
\end{tabular}

*Em relação a área privada residencial

\begin{tabular}{l|c|c|c|c|c|c}
\hline EMPREENDIMENTO TIPO 9 (Lotes em ZEIS 2 ou 3) \\
\hline & $\%$ & Área $\left(\mathrm{m}^{2}\right)$ & $\begin{array}{c}\text { Área } \\
\text { Computável } \\
\left(\mathrm{m}^{2}\right)\end{array}$ & $\begin{array}{c}\text { Área por } \\
\text { UH }\left(\mathrm{m}^{2}\right)\end{array}$ & Unidades & $\begin{array}{c}\text { População } \\
\text { equivalente }\end{array}$ \\
\hline Total & $\mathbf{1 0 0 , 0 \%}$ & $\mathbf{1 1 0 5 4 8 , 5 8}$ & - & - & $\mathbf{6 5 2 8}$ & $\mathbf{2 0 8 8 8}$ \\
\hline Área Privada - Uso Residencial & $\mathbf{9 0 , 0} \%$ & $\mathbf{9 9 4 9 3 , 7 2}$ & $\mathbf{1 9 8 9 8 7 , 4 4}$ & - & - & - \\
\hline Habitação de Mercado Popular & $10,0 \%$ & 11054,86 & 44219,43 & 70,00 & 632 & 2021 \\
\hline Habitação de Interesse Social & $\mathbf{8 0 , 0 \%}$ & $\mathbf{8 8 4 3 8 , 8 6}$ & 353755,46 & 60,00 & 5896 & 18867 \\
\hline Área Privada - Uso Não Residencial & $\mathbf{1 0 , 0 \%}$ & $\mathbf{1 1 0 5 4 , 8 6}$ & $\mathbf{4 4 2 1 9 , 4 3}$ & - & - & - \\
\hline
\end{tabular}

\begin{tabular}{l|c|c|c|c|c|c}
\hline EMPREENDIMENTO TIPO 10 (Lotes em ZEIS 5) \\
\hline & $\%$ & Área $\left(\mathrm{m}^{2}\right)$ & $\begin{array}{c}\text { Área } \\
\text { Computável } \\
\left(\mathrm{m}^{2}\right)\end{array}$ & $\begin{array}{c}\text { Área por } \\
\text { UH }\left(\mathrm{m}^{2}\right)\end{array}$ & Unidades & $\begin{array}{c}\text { População } \\
\text { equivalente }\end{array}$ \\
\hline Total & $\mathbf{1 0 0 , 0 \%}$ & $\mathbf{6 0 0 9 6 , 4 5}$ & - & - & $\mathbf{3 2 1 7}$ & $\mathbf{1 0 1 9 7}$ \\
\hline Área Privada - Uso Residencial & $\mathbf{9 0 , 0} \%$ & $\mathbf{5 4 0 8 6 , 8 1}$ & $\mathbf{1 0 8 1 7 3 , 6 1}$ & - & - & - \\
\hline Multifamiliar de Médio Padrão & $10,0 \%$ & 6009,65 & 24038,58 & 100,00 & 240 & 673 \\
\hline Habitação de Mercado Popular & $40,0 \%$ & 24038,58 & 96154,32 & 70,00 & 1374 & 4396 \\
\hline Habitação de Interesse Social & $40,0 \%$ & 24038,58 & 96154,32 & 60,00 & 1603 & 5128 \\
\hline Área Privada - Uso Não Residencial & $\mathbf{1 0 , 0 \%}$ & $\mathbf{6 0 0 9 , 6 5}$ & $\mathbf{2 4 0 3 8 , 5 8}$ & - & - & - \\
\hline
\end{tabular}

